Universidad de Lima

Facultad de Comunicación

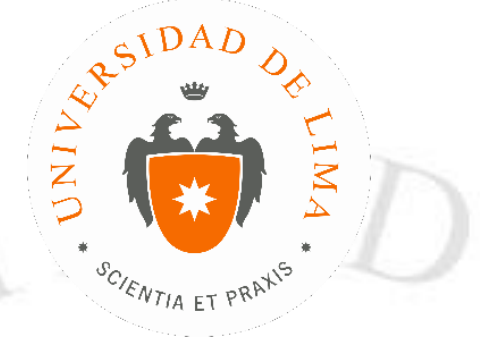

\title{
LANZAMIENTO DE LA FRAGANCIA PULSO DE CHRISTIAN MEIER DE ÉSIKA: CONECTANDO CON EL CONSUMIDOR
}

Trabajo de Suficiencia Profesional para optar el Título Profesional de Licenciado en

Comunicación

Rosario Marcela Vidurrizaga Costa

Código 801014

Asesora

Berta Beatriz Paredes Maibach

Lima - Perú

Junio 2017 


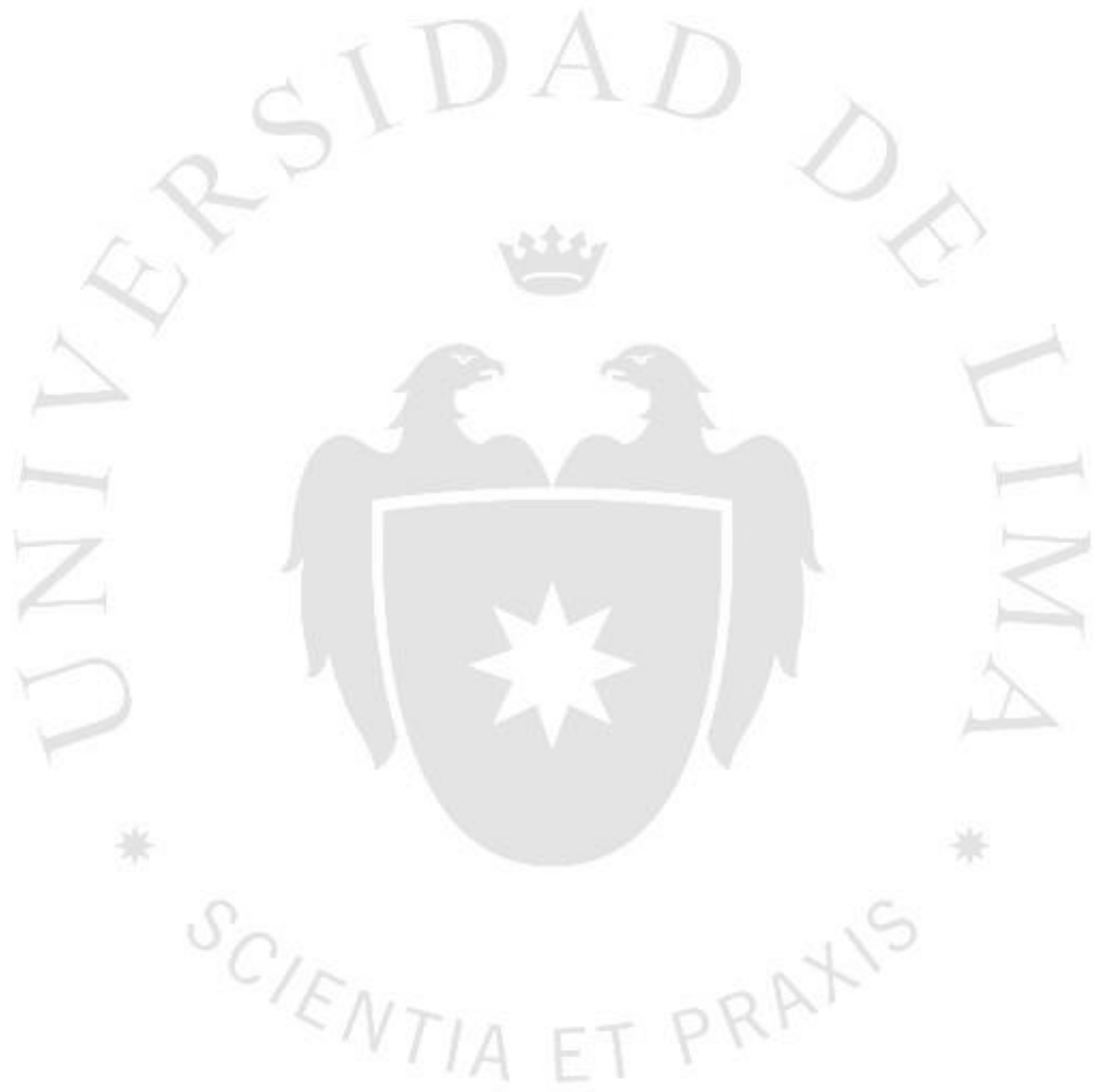




\section{LANZAMIENTO DE LA FRAGANCIA PULSO DE CHRISTIAN MEIER DE ÉSIKA: CONECTANDO CON EL CONSUMIDOR}




\section{TABLA DE CONTENIDO}

\section{INTRODUCCIÓN.}

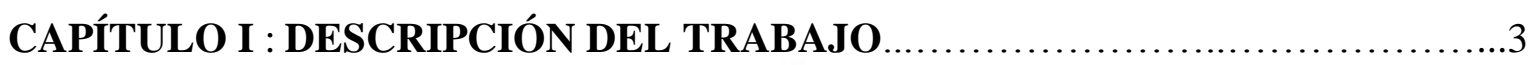

1.1. Historia y Situación de la marca.........................................

1.1.1. Portafolio cosmético.............................................

1.1.2. El canal de distribución: La Venta Directa.................................4

1.1.3. Perfil del grupo objetivo: Consumidores y clientes.......................5

1.2. El Proceso Stage Gate (Etapa Puerta)...................................5

1.3. Descubrimiento de la Idea................................................

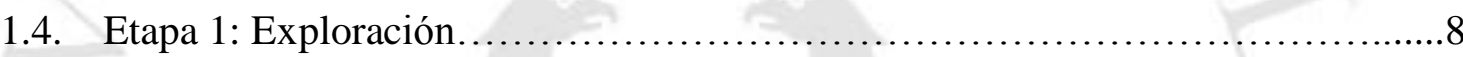

1.4.1. El mercado de fragancias masculinas..................................... 8

1.4.2. Evaluación de oportunidad en Familias Olfativas.............................8

1.4.3. Selección de tendencia conceptual.....................................

1.4.4. Análisis de la competencia...........................................

1.4.5. Análisis técnico.....................................................10

1.4.6. Análisis financiero............................................ 10

1.5. Etapa 2: Construcción del Business Case para pase a Diseño...................11

1.6. Etapa 3: Diseño de concepto, fórmula, envase. Aprobación pre-prototipo........12

1.7. Etapa 4: Evaluación con consumidor - Aprobación prototipo....................13

1.7.1. Concepto y Key Brand Benefit (KBB) .............................. 13

1.7.2. Concept Board ......................................................... 13

1.7.3. Envase ganador: diseño industrial, gráfico y nombre.....................14

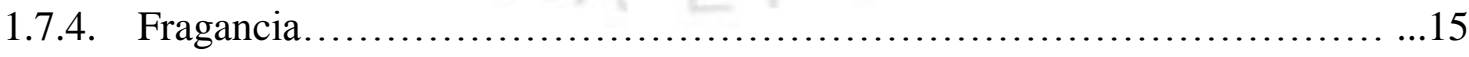

1.8. Lanzamiento........................................................ 16

1.8.1. Estrategia de medios a cliente y consumidor...............................16

1.8.2. Estrategia a Fuerza de Ventas..................................... 19

1.8.3. Estrategia de Relaciones Públicas.....................................21

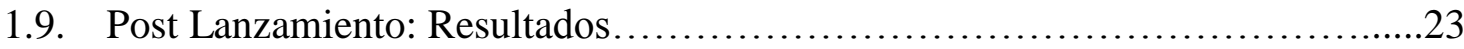




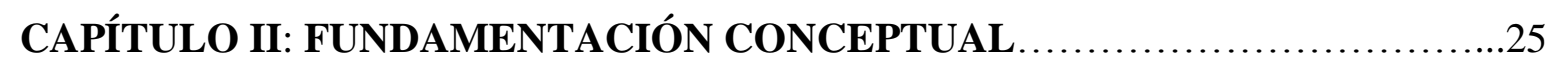

2.1. Importancia de Productos Nuevos.....................................25

2.2. Evaluación previa al inicio del diseño de la fragancia $\ldots \ldots \ldots \ldots \ldots \ldots \ldots \ldots \ldots . \ldots \ldots$

2.2.1. Evaluación de mercado........................................... 26

2.2.2. Evaluación ruta conceptual.........................................29

2.2.3. Evaluación oportunidad olfativa..................................... 31

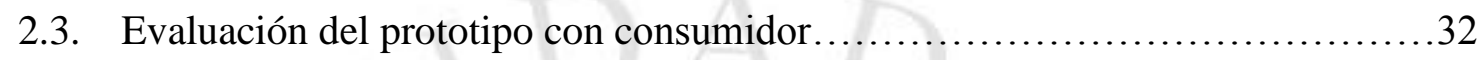

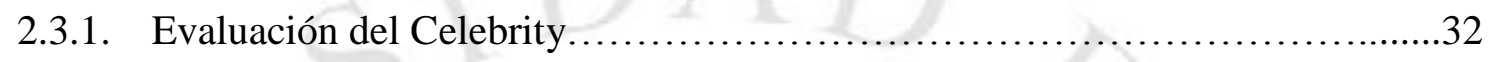

2.3.2. Evaluación cualitativa concepto, board, nombre y diseño....................33

2.3.3. Evaluación cuantitativa fragancia, concepto y board.........................35

CAPÍTULO III: LECCIONES APRENDIDAS ................................ 38

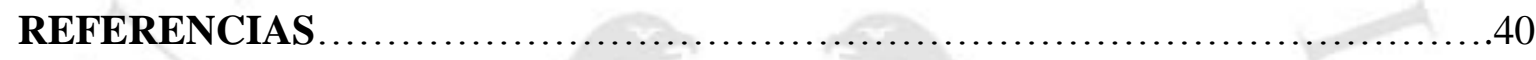

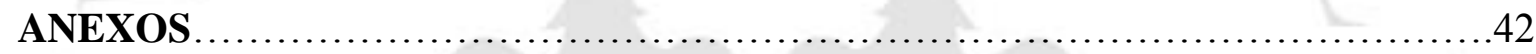




\section{ÍNDICE DE TABLAS}

Tabla 1.1. Resultados de lanzamiento Pulso versus objetivos...................24

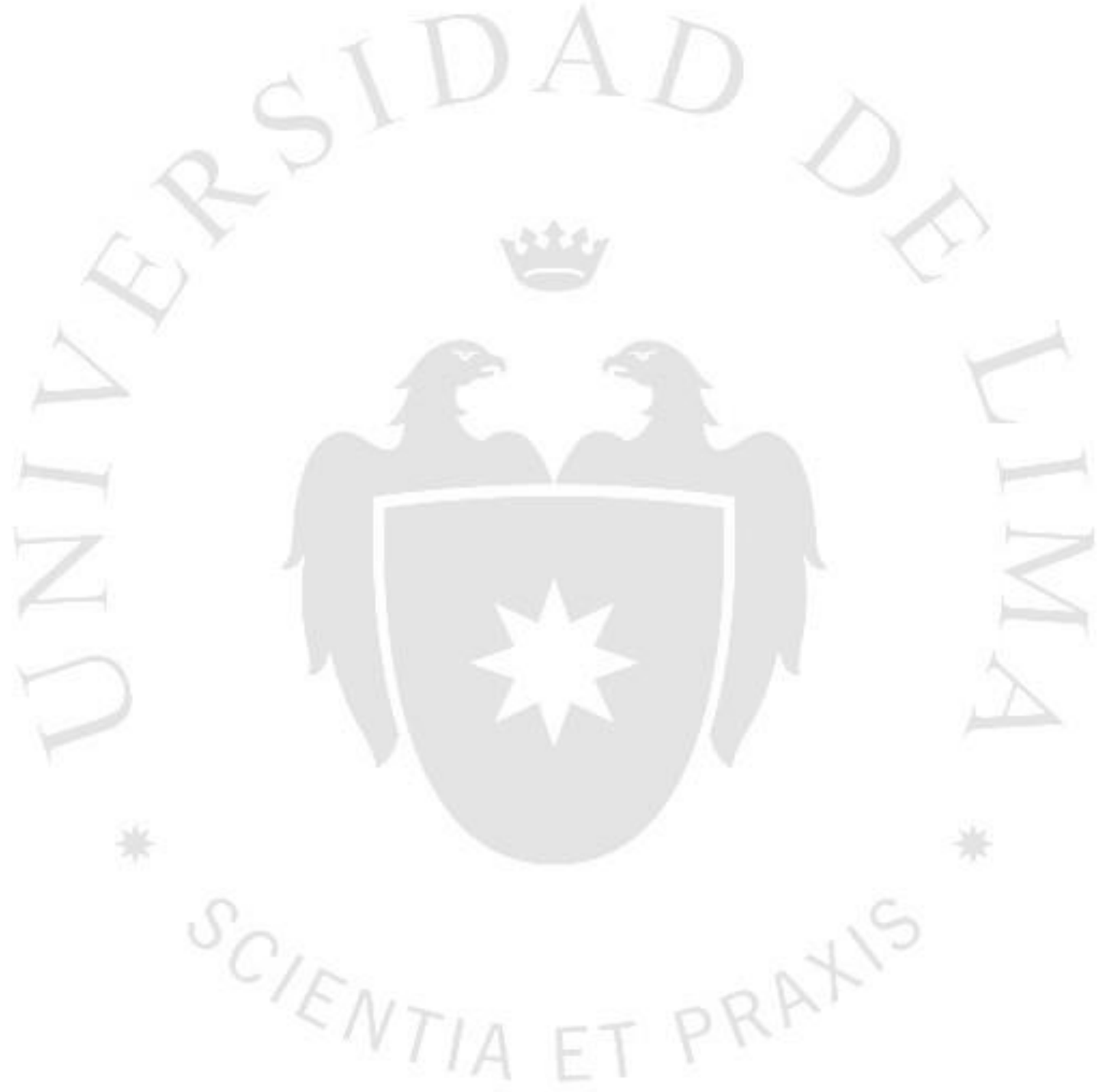




\section{ÍNDICE DE FIGURAS}

Figura 1.1. Cronología Evolución marcas Belcorp................................

Figura 1.2. Proceso Stage Gate o Etapa Puerta.....................................6

Figura 1.3. Lanzamientos internacionales tendencia Status Quo.......................

Figura 1.4. Temptation de Unique- Yanbal....................................10

Figura 1.5. Business Case o Caso de Negocio..........................................11

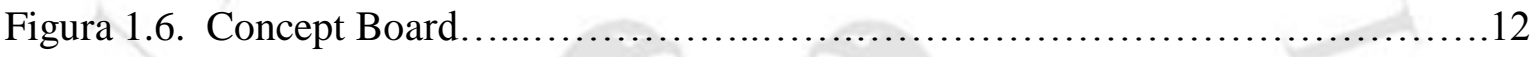

Figura 1.7. Concepto aprobado.............................................. 13

Figura 1.8. Board aprobado................................................... 14

Figura 1.9. Diseño de envase ganador........................................ 15

Figura 1.10. Pirámide olfativa de Pulso e inspiración de la perfumista...................15

Figura 1.11. Ficha de comercial TV Pulso........................................ 17

Figura 1.12. Paneles Vía Pública.................................................. 18

Figura 1.13. Aviso Revista.................................................. 18

Figura 1.14. Juego interactivo página web.....................................19

Figura 1.15. Páginas Catálogo Lanzamiento y Mantenimiento........................... 19

Figura 1.16. Afiche para Fuerza de Ventas.....................................20

Figura 1.17. Material motivador evento para Consultoras............................21

Figura 1.18. Cobertura de eventos de lanzamiento...............................22

Figura 1.19. Rebote en carátulas de revistas ej. Carrusel de Colombia....................22 
Figura 1.20. Cobertura lanzamiento nuevos países................................23

Figura 2.1. Distribución por categoría venta directa cosmética........................27

Figura 2.2. Distribución de ventas Ésika por países..............................28

Figura 2.3. Artistas evaluados para el proyecto..................................... 34

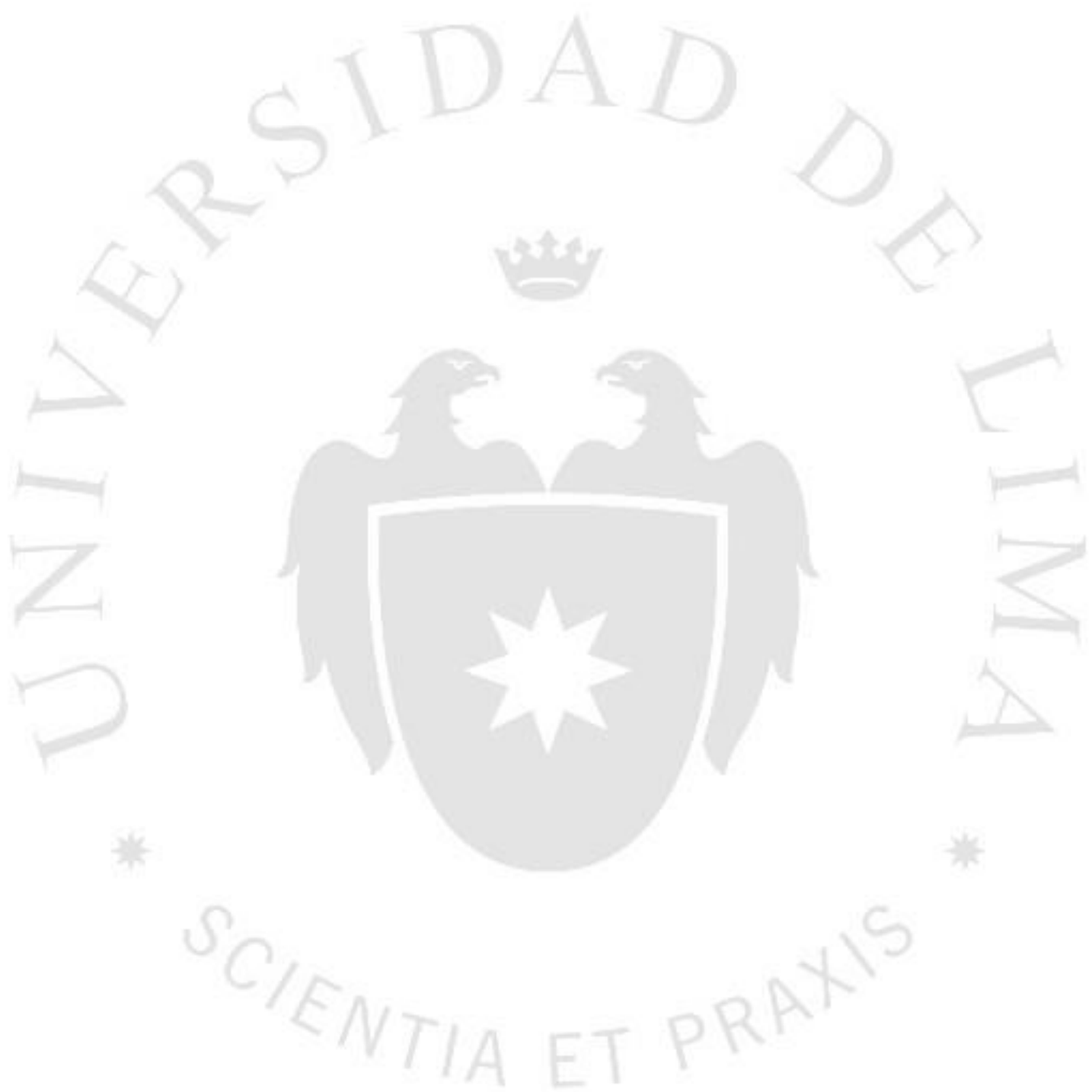




\section{ÍNDICE DE ANEXOS}

Anexo 1: El mundo de las Fragancias......................................42

Anexo 2: Tendencias conceptuales analizadas para el proyecto...................45

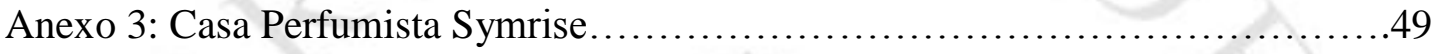

Anexo 4: La Competencia...................................................50

Anexo 5: Biografía perfumista........................................52

Anexo 6: Distribución de mercado por tipos de fragancia.......................53 


\section{INTRODUCCIÓN}

Este trabajo consiste en compartir el desarrollo del Lanzamiento de la fragancia masculina Pulso de Christian Meier de Ésika, en el 2009 bajo mi gestión como Gerente de Innovación y Desarrollo Categoría Fragancias, posición que ocupé del 2007 al 2008 y, luego como Gerente de Marketing de la marca Ésika del 2009 al 2013. El trabajo muestra la relevancia del profundo conocimiento del consumidor para lograr una fuerte conexión con la marca y abarca el trayecto desde la idea inicial hasta el análisis de resultados del proyecto. Este lanzamiento tiene como característica especial haber sido la primera experiencia de Ésika en asociarse con un artista o celebrity, en este caso, un peruano altamente reconocido a nivel de Latinoamérica. También fue la primera vez que Ésika dio apoyo publicitario a un producto dirigido a hombres a nivel de medios masivos y relaciones públicas.

La categoría de fragancias es altamente competitiva, cada año se lanzan en el mundo más de 1,500 fragancias según el conteo de Michael Edwards, experto en perfumería y editor de la prestigiosa guía anual "Fragrances of the World". Dentro de este intenso contexto de estímulos donde también, según esta guía, los expertos estiman que el $80 \%$ de las nuevas fragancias no vivirá más de 2 años, Ésika se propuso desarrollar una fragancia memorable, que conectara emocionalmente con el consumidor de manera distintiva y a la vez produzca altas ventas y rentabilidad.

Aun cuando Ésika contaba con un amplio portafolio de aromas masculinos, sólo Kalos Sport era considerada como "Clásico" por su éxito sostenido durante años en todos los países. La fragancia Pulso se lanzó en campaña 8 (junio) del 2009 en simultáneo en 9 países de Latino América (Perú, Colombia, Bolivia, Chile, Venezuela, Ecuador, México, Guatemala y El Salvador) y logró el desafío de convertirse en un "Clásico" habiendo podido albergar 2 versiones adicionales con el mismo artista: Bravío lanzada en el 2011 y Leyenda en el 2016. Hoy las 3 fragancias continúan construyendo conexión con el cliente y consumidor y aportando alto valor a la marca. 


\section{El proyecto tiene por objetivos por lo tanto mostrar:}

- Lanzamiento de la fragancia masculina Pulso de Christian Meier de Ésika con un concepto motivador y diferenciado que construya valor de marca y conecte con el consumidor y clientes aportando altas ventas y participación de mercado.

- Lanzamiento de la campaña de comunicación integral considerando publicidad masiva, material a fuerza de ventas y activaciones de relaciones públicas que apoyen los objetivos comerciales generando conexión con el consumidor y clientes. 


\section{CAPÍTULO I: DESCRIPCIÓN DEL TRABAJO}

\subsection{Historia y Situación de la Marca}

La fragancia masculina Pulso de Christian Meier es una submarca de la marca ÉSIKA, que junto con L’BEL y CYZONE pertenecen a la corporación peruana Belcorp.

Belcorp es una empresa cosmética de venta directa peruana, con operaciones en 15 países de América. La compañía se inició en 1966 como Productos Favel S.A, fundada por Fernando Belmont Bar, padre de Jorge, Eduardo y Juan Fernando. La empresa se inició maquilando para Helena Rubinstein y L’Oreal. En 1967 lanzó la marca Yanbal y en 1986 Eduardo Belmont Anderson y su hermano Fernando se independizaron formando 2 compañías de belleza. Eduardo fundó lo que hoy es Belcorp con las marcas Yanbal en Perú y EBEL (hoy L’BEL) en Colombia y Chile. Fernando fundó Unique en Perú y Yanbal en el extranjero. La sede principal de la corporación se encuentra en Lima, sin embargo parte de las áreas de Innovación y Compras están en Bogotá junto con la Planta Principal de la empresa.

Figura 1.1

Cronología Evolución marcas Belcorp

\begin{tabular}{|c|c|c|c|c|c|c|c|c|}
\hline 1966 & 1967 & 1982 & 1984 & 1986 & 1997 & 1999 & 2003 & 2008 \\
\hline $\begin{array}{l}\text { Fernando } \\
\text { Belmont Bar } \\
\text { funda Favel }\end{array}$ & Nace Yanbal & $\begin{array}{l}\text { Fernando } \\
\text { Belmont A. } \\
\text { crea Unique } \\
\text { para Perú y } \\
\text { Yanbal para } \\
\text { extranjero }\end{array}$ & $\begin{array}{l}\text { Eduardo } \\
\text { Belmont A. } \\
\text { crea EBEL } \\
\text { para Perú y } \\
\text { extranjero }\end{array}$ & $\begin{array}{l}\text { - Hermanos se } \\
\text { separan. } \\
\text { - FBA queda } \\
\text { con Unique y } \\
\text { Yanbal } \\
\text { Internacional } \\
\text { - EBA con } \\
\text { Yanbal y } \\
\text { EBEL }\end{array}$ & $\begin{array}{l}\text { - Yanbal Perú } \\
\text { pasa a } \\
\text { Fernando } \\
\text { - Productos } \\
\text { Yanbal pasan } \\
\text { a catálogo } \\
\text { EBEL }\end{array}$ & Nace Cyzone & Nace Ésika & $\begin{array}{l}\text { EBEL } \\
\text { cambia a } \\
\text { L'BEL }\end{array}$ \\
\hline
\end{tabular}

Fuente: Elaboración propia en base a información interna Belcorp e Infante (2011)

Ésika nació en el año 2003 con maquillaje como su categoría principal. Su slogan “Quién quieres ser hoy?” invitaba a las mujeres a fantasear y cambiar para ser más felices. (Infante, 2011). Hoy Ésika es la marca de mayor venta de la corporación con un peso de $50 \%$, así como también representa las mayores utilidades. 
El propósito de Belcorp es: "Impulsamos belleza para lograr realización personal a través de nuestras marcas L`BEL, Ésika y Cyzone generando un impacto positivo en millones de personas de América Latina, con una red de 800 mil consultoras en 15 países" (Belcorp.biz,2016).

Los Valores de Belcorp son: somos auténticos, cercanos, emprendedores y apasionados. Los productos que se desarrollan y sus posicionamientos deben ser coherentes con esta estrategia corporativa para construir la imagen de marca de Ésika.

\subsubsection{Portafolio Cosmético}

El portafolio cosmético de Ésika se divide en 4 categorías:

1. Maquillaje

2. Fragancias: Finas Femeninas, Masculinas y Unisex, Colonias

3. Cuidado Personal: cabello, desodorantes, talcos

4. Tratamientos Facial y Corporal

Hasta el 2006 sólo maquillaje contaba con inversión publicitaria; aunque las fragancias finas traían mayores "ventas (45\%) y utilidad (46\%)" (Diagnóstico Fragancias Ésika, 2010). Adicionalmente, eran productos muy valorados al ser de mayor desembolso y por sus atractivos envases. En el 2007, Ésika lanzó la fragancia femenina Ainnara, la primera con pauta de televisión. Tras el positivo impacto publicitario en ventas y recordación de marca, el presupuesto anual incluyó 2 campañas para fragancias, 2 para maquillaje y una para imagen de marca. Cabe destacar que la pauta de fragancias era solamente para las femeninas, hacerlo para un producto para hombres era impensable.

\subsubsection{El canal de distribución: La Venta Directa}

La venta de Ésika es apoyada con catálogos para las casi 1 millón de consultoras. Se desarrollan 18 catálogos anuales para las 18 campañas con una vigencia promedio de 3 semanas cada una. 
Las consultoras suelen recomendar productos a sus clientes, en especial fragancias a sus clientes masculinos. Ellas cuentan con muestras en sachets y probadores para que sus clientes sientan los aromas en su piel; las páginas de catálogo tienen barnices y discovers para oler el aroma.

Una debilidad de la Venta Directa frente al Retail es su menor percepción de valor pues el público atribuye mayor duración a las fragancias de Retail considerándolas "de marca”. Por esta razón, un reto constante para Ésika es construir un mejor Brand Equity a través de la experiencia de sus productos y su comunicación. En el caso de Pulso, un celebrity podría impulsar positivamente esa percepción de valor.

\subsubsection{Perfil del Grupo Objetivo: Consumidores y clientes}

Los clientes foco de Ésika son mujeres preocupadas por el bienestar de sus familias. En el caso de fragancias masculinas existen clientes mujeres y hombres. Las mujeres compran para sus parejas porque quieren que ellos huelan rico y "a limpio" y estén bien presentados, cumpliendo un buen rol de representantes de la familia.

Los beneficios que los hombres buscan de las fragancias son sentirse atractivos y conquistadores hacia sus parejas actuales o futuras. Ellos quieren que las damas alaben su aroma diciéndoles "qué rico hueles". Las fragancias les dan la seguridad de tener "buena presencia" y completar su apariencia para desenvolverse bien en todos sus roles. Además, desean aromas duraderos, aunque suelen echarse abundante fragancia más de una vez en el día y sobretodo en la noche si van a salir. No se tienen cifras exactas del porcentaje de compradores masculinos en venta directa, el área de ventas estima que sería cerca del $40 \%$.

El target pertenece a los niveles socio económico bajo, medio bajo y medio en Perú y estratos 2,3 y 4 de Colombia que equivalen en el mismo orden a los de Perú. Ambos países son los principales para Ésika. La edad del Público Objetivo es de 28 a 45 años.

\subsection{El Proceso Stage Gate (Etapa Puerta)}

El proceso que Belcorp aplica para el desarrollo de Productos Nuevos es el Stage Gate (Etapa/Puerta), metodología creada por el doctor Robert G. Cooper del Product Development 
Institute Inc.y Profesor Emérito de la Universidad McMaster de Hamilton, Canadá. Este proceso es utilizado por grandes empresas en el mundo como una disciplina que logra lanzamientos exitosos a velocidad.

En cada etapa (stage) se dan actividades paralelas que serán sustentadas y aprobadas en una sesión "puerta" (gate) antes de pasar a la siguiente etapa. El proceso se inicia con el “Descubrimiento de la Idea" y termina con la evaluación Post Lanzamiento:

\section{Descubrimiento}

2. Etapa 1: selección de ideas

3. Etapa 2: Business Case y pase a diseño

4. Etapa 3: Diseño de concepto, fórmula, envase. Aprobación pre-prototipo

5. Etapa 4: Evaluación con consumidor-Aprobación prototipo

6. Etapa 5: Desarrollo de producto, lanzamiento

7. Evaluación Post Lanzamiento

Figura 1.2

Proceso Stage Gate o Etapa Puerta

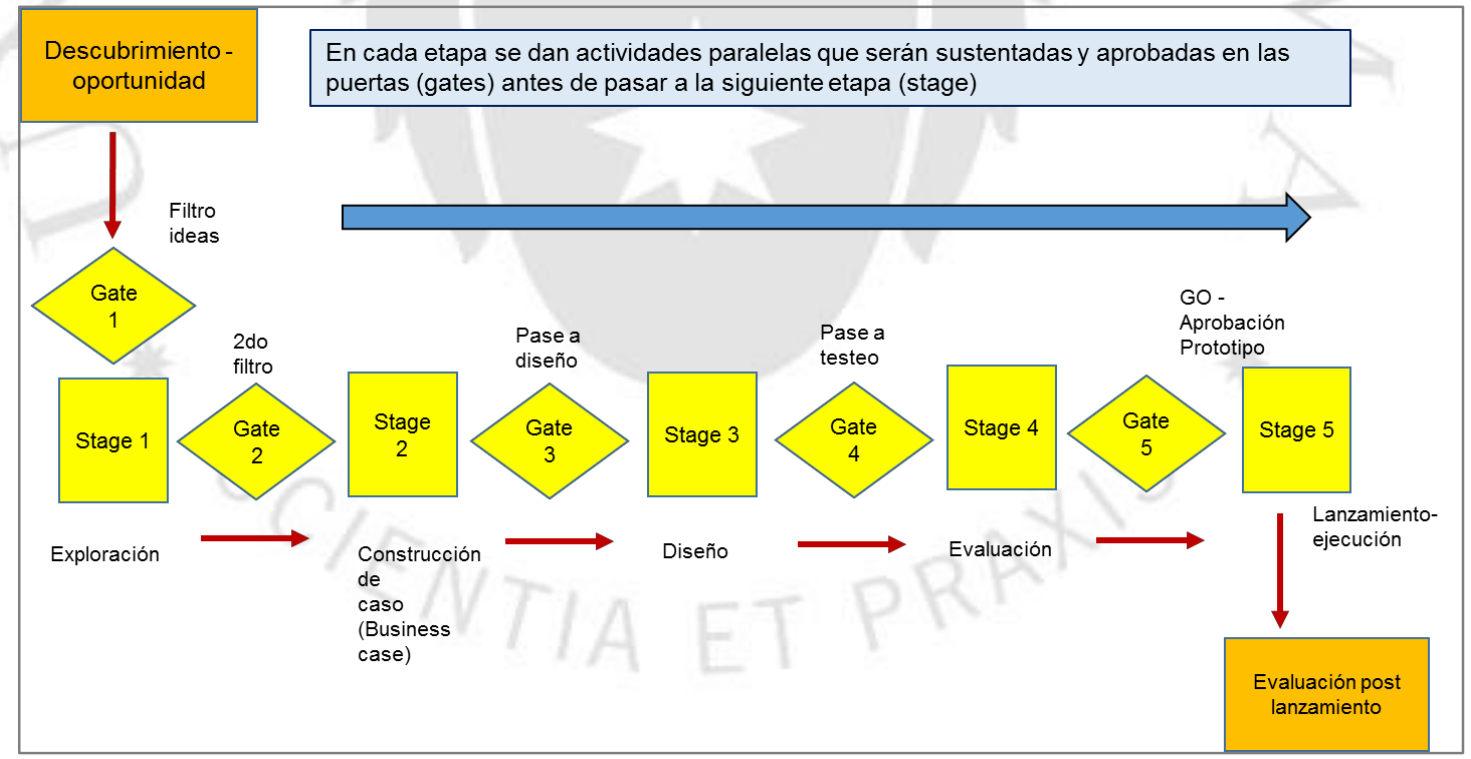

Fuente: Cooper, R.G. (2001). Winning at New Products: Accelerating the Process from Idea to Launch. New York: Basic Books. p.130 traducido 


\subsection{Descubrimiento de la Idea}

Para llegar a "La Idea" se realiza un análisis de negocio inicial, priorizándose la innovación y cuidando que esta idea mantenga alineación con la estrategia de la empresa. El efectivo manejo de "La Idea" es el principal impulsor del performance del producto nuevo según el modelo y estudio de "Excelencia Global en Innovación" de Arthur D. Little (2016).

La idea innovadora y retadora era el lanzar una fragancia masculina con un celebrity. Podría ser un cantante o actor, debería ser muy atractivo y conocido en la mayoría de países donde Ésika opera. Tendría que agradar a los hombres y mujeres teniendo en cuenta los "peros" hacia los artistas atractivos por parte de los hombres por el machismo latinoamericano. Debería ser cercano y auténtico para estar alineado a la estrategia Belcorp. En ese entonces, Belcorp no tenía aun experiencia en contratos con artistas ni manejo de desarrollo de productos con ellos, uso de sus nombres, etc.

La fragancia debería ser de un nivel de precio alto dentro del portafolio para transmitir más valor y por lo tanto aportar en la construcción de calidad. Sería de $100 \mathrm{ml}$ continuando con la capacidad tradicional de Ésika y que parecía ser una ventaja frente a Unique -Yanbal que tiene varias fragancias de $75 \mathrm{ml}$.

El aroma debería ser muy masculino y moderno sin llegar a ser disruptivo para garantizar amplia aceptación.

El proyecto sería de altas expectativas de ventas al igual que su inversión en desarrollo y publicidad, donde además del contrato con el celebrity, se contaría con comercial de TV, algo nunca pensado para un producto masculino, pero necesario para marcar la diferencia frente a la competencia de manera integral. Un reto adicional era que Ésika es una marca posicionada como femenina y con una historia de comunicación masiva dirigida solamente a las mujeres donde las fragancias masculinas no eran consideradas productos estratégicos a pesar de su alta venta y rentabilidad.

Con esta propuesta se llegó a la Puerta 1 (Gate 1) lográndose la aprobación de la idea. Cabe señalar que en el 2008 la aprobación (gatekeeper) de este Gate estuvo a mi cargo como Gerente de Innovación de la categoría fragancias. Con el "Go" al proyecto inicial se daba 
pase a la siguiente etapa donde se profundizaría más en el análisis y en el sustento estratégico y comercial de desarrollar una fragancia masculina estratégica y prioritaria para Ésika.

\subsection{Etapa 1: Exploración}

En esta etapa se hizo un análisis más profundo de mercado, técnico y financiero. Para evaluar el potencial de la idea y sus posibles caminos estratégicos, el análisis de mercado incluyó evaluación del sector de fragancias masculinas, la oportunidad olfativa, tendencias conceptuales y la competencia.

\subsubsection{El mercado de fragancias masculinas}

Se observó que el mercado de fragancias era altamente atractivo en cuanto a volumen y tendencia de crecimiento en Latinoamérica. Dentro de la categoría fragancias el tipo más grande era el de masculinas a la vez de ser el de mayor participación de ventas en Ésika. Los países Colombia y Perú quedaron seleccionados como mercados foco priorizando a Colombia por ser el país líder en ventas de la corporación. En niveles socio económicos los

segmentos de mayor participación de mercado en fragancias masculinas eran el medio bajo y bajo justamente donde Ésika era más fuerte. En conclusión, la oportunidad comercial en el mercado de fragancias masculinas era altamente potencial para un proyecto de alta inversión.

\subsubsection{Evaluación de oportunidad en Familias Olfativas}

Se propone que la fragancia sea de ruta olfativa Aromática o Fougere moderno como familia principal lo cual le daría frescura y masculinidad. Debería contar con acordes de madera para dar la sofisticación y notas orientales para aportar seducción y mayor durabilidad. (Anexo 1)

\subsubsection{Selección de la tendencia conceptual}

Según los últimos lanzamientos a nivel internacional de fragancias que se analizaron 10 tendencias como alternativas de ruta conceptual en conjunto con el equipo de publicidad y aplicando aprendizajes de estudios previos con consumidor. (Anexo 2) 
Se seleccionó la tendencia Status Quo que presenta al hombre viviendo una experiencia VIP como algo natural, con una presencia imponente, muy viril que transmite una fuerte personalidad y sofisticada sensualidad. Como códigos importantes, vemos presencia de imágenes blanco y negro. Ejemplos: The One de Dolce \& Gabanna, Silver Shadow de Davidoff, Gucci pour Homme, Exceptionnel Homme de Mont Blanc.

Esta tendencia usada como fuente para inspiración del concepto aportaría aspiracionalidad, percepción de calidad y valor a la fragancia. Dimos la recomendación de reforzar la seducción en el concepto como algo natural en el personaje para darle autenticidad y cercanía la historia. La historia estaría acorde con el nivel de precio A del nuevo producto.

\section{Figura 1.3}

Lanzamientos internacionales tendencia Status Quo

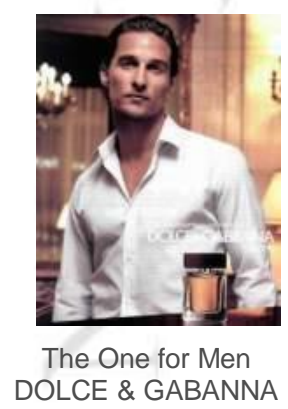

LCE \& GABANNA

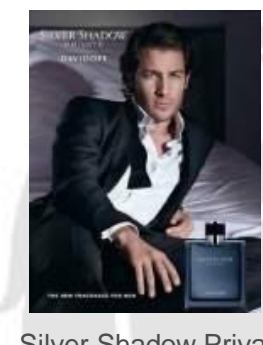

Silver Shadow Private DAVIDOFF

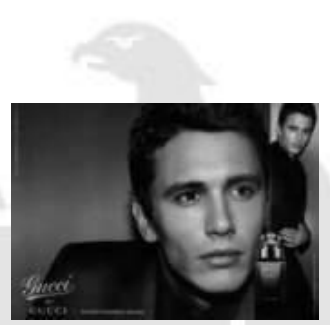

Gucci Pour Homme GUCCI

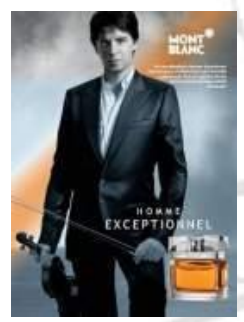

Exceptionnel Homme MONT BLANC

Con la tendencia aprobada y basándose en estudios de Códigos de Seducción Irresistible, explicado en el capítulo de Fundamento Conceptual, la casa perfumista Symrise (Anexo 3) presentó una idea conceptual base para trabajar el primer concepto a presentar en Business Case y luego validar con consumidor.

\subsubsection{Análisis de la competencia}

Luego de analizar distintas fragancias de la competencia de Venta Directa y Retail (Anexo 4) desde el punto de vista conceptual, familia olfativa, ranking, participación de mercado y nivel de precio, se seleccionó como principal producto competidor y fuente de negocio a Temptation de Unique/Yanbal por las siguientes características:

- Fragancia top 10 del ranking en Perú y Colombia 
- Concepto de seducción

- $\quad$ Producto clásico de la competencia

- $\quad$ Alto valor percibido

- $\quad$ Nivel de precio $15 \%$ por encima que nuestro proyecto.

- Capacidad de $100 \mathrm{ml}$

- Familia olfativa Fougere Aromatic Woody ruta probable de nuestro proyecto

- Aroma intenso y de larga duración.

Figura 1.4

Temptation de Unique - Yanbal

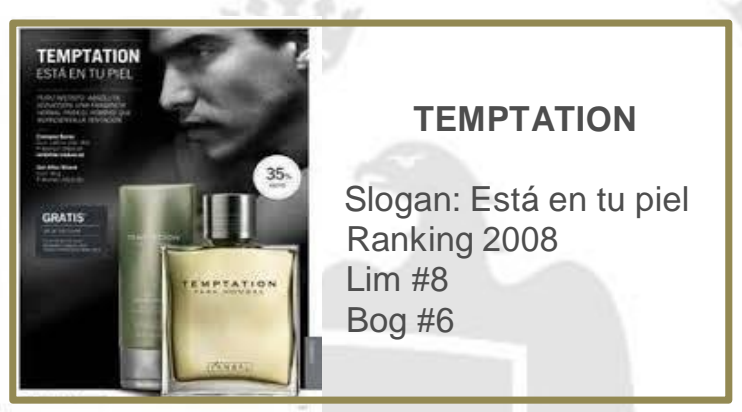

\subsubsection{Análisis técnico:}

Se validó que había disponibilidad de los mejores diseñadores e ingenieros para el diseño industrial y de moldes así como también proveedores de calidad aprobados para abastecer las cantidades requeridas a tiempo de un nuevo diseño de envase y sobre tapa. Así mismo se validó la capacidad de planta para maquilar las fragancias desde Lima y Bogotá y así abastecer a los 9 países Ésika.

\subsubsection{Análisis financiero:}

Luego del análisis de costos, precio propuesto y ventas estimadas se aprobó la rentabilidad del proyecto luego de las inversiones en diseño y moldes. Aún no se incluía análisis de inversión en publicidad ni estimación de contrato y actividades de PR.

Con este análisis se pasó aprobación en la puerta (gate) 2 que nuevamente estaba en el área de Innovación de Belcorp aun sin participación de la marca. 


\subsection{Etapa 2: Construcción del Business Case para de Pase a Diseño.}

El Business Case "Hombre Irresistible" fue preparado por el equipo de Innovación de Fragancias y presentado en Gate 3 a la Directora de la marca Ésika por la líder del proyecto y la Gerente. Este Business Case incluyó los siguientes puntos ya revisados en este trabajo y cuyos sustentos serán presentados en el capítulo de Fundamentación Conceptual:

Figura 1.5

Business Case o Caso de Negocio

\begin{tabular}{|c|c|}
\hline \multicolumn{2}{|r|}{ BUSINESS CASE } \\
\hline Marca & Ésika \\
\hline Proyecto & Fragancia Masculina Hombre Irresistible \\
\hline $\begin{array}{l}\text { 1. Oportunidad de } \\
\text { mercado }\end{array}$ & $\begin{array}{l}\text { - Mercado de UŚ } 196 \mathrm{MM} \text { en Co y } 97 \mathrm{MM} \text { en Pe } \\
\text { - Venta interna Ésika masculinas pesa } 44 \% \text { vs } 32 \% \text { de femeninas } \\
\text { - Ésika tiene } 6 \text { y } 5 \text { fragancias en el TOP } 10 \text { de Col y Perú. Yanbal } 1 \text { y } 3\end{array}$ \\
\hline 2. Objetivos del proyecto & $\begin{array}{l}\text { - Venta estimada anual en USD y UU } \\
\text { - Share objetivo Col:3.2\%, Lim:3.0\% } \\
\text { - Ranking Col: } 4 \text {, Lim:3 } \\
\text { - Elevar TOM y Awareness de Ésika } \\
\text { - Elevar percepción de calidad de fragancias } \\
\text { - Mantener o incrementar peso de } 23 \% \text { de productos nuevos }\end{array}$ \\
\hline 3. Nivel de Precio, costos & - Nivel de Precio A, costo x según objetivos de rentabilidad \\
\hline 4. Tendencia Conceptual & - Status Quo \\
\hline 5. Familia Olfativa & - Aromatic Fougere, sub familia Woody Oriental. \\
\hline 6. Casa Perfumista & - Symrise \\
\hline 7. Ruta Conceptual & $\begin{array}{l}\text { Él posee un poder de seducción innato que le permite conquistar a } \\
\text { cualquier mujer a través de su mirada penetrante y su media sonrisa. } \\
\text { Increíblemente atractivo e interesante. Es un hombre fascinante que } \\
\text { disfruta de la vida y valora su libertad. } \\
\text { Es carismático, auténtico, seguro de sí mismo, simplemente...imposible de } \\
\text { imitar }\end{array}$ \\
\hline 8. Valores a transmitir & Seducción y carisma \\
\hline 9. Key Competitor & Temptation de Unique/Yanbal. Rkg 6 en Colombia, 8 en Perú \\
\hline 10. Ventaja Diferencial & $\begin{array}{l}\text { - Uso de Celebrity. Debe ser muy atractivo, auténtico, cercano a hombre y } \\
\text { mujeres, muy conocido en Latam } \\
\text { - Publicidad masiva }\end{array}$ \\
\hline $\begin{array}{l}\text { 11. Investigación de } \\
\text { mercados }\end{array}$ & $\begin{array}{l}\text { - Cualitativos para a) Códigos de Seducción, b) Selección de celebrity y c) } \\
\text { Diseño de concepto y Envase } \\
\text { - Cuantitativo HUT para evaluación de aroma }\end{array}$ \\
\hline $\begin{array}{l}\text { 12. Campaña de } \\
\text { lanzamiento }\end{array}$ & - C08/2009. 9 países en simultáneo \\
\hline
\end{tabular}

El Gate 3 contó con la aprobación de la Directora de la marca Ésika y su equipo de Marketing. Con el Business Case aprobado se pasó a la etapa 3 (stage 3) o Diseño. 


\subsection{Etapa 3: Diseño de concepto, fórmula, envase. Aprobación pre-prototipo}

Durante esta etapa trabajó el equipo multifuncional responsable del Proyecto Hombre Irresistible. Este equipo estaba conformado por marketing, redactores creativos, diseñadores industriales y gráficos, ingenieros de envases, químicos, compras, controller de proyectos, costos, registros sanitarios, marcarios y planta. El líder de marketing cumple el rol de líder de todo el equipo siendo vocero del consumidor y de la personalidad de la marca. Al final de esta etapa se presentaron los estímulos que se evaluarían con consumidor en la puerta 4 , también llamada "Presentación de Pre-Prototipo". En este gate se aprobó el pase a evaluaciones cualitativas y cuantitativas con consumidor los siguientes estímulos:

\section{Evaluaciones cualitativas:}

\section{Evaluación cualitativa 1}

- El concepto

- El Board de imágenes sin celebrity para no sesgar

- Alternativas de diseño industrial o frascos, con 2 opciones de diseño gráfico

- Cajas

- Nombres para la fragancia

- Envases de competencia internacional como benchmarks

\section{Evaluación cualitativa 2}

- Evaluación cualitativa exclusiva para selección del Celebrity con candidatos Alejandro Fernández, Rafael Novoa, Christian Meier

Figura 1.6

Board de imágenes del concepto

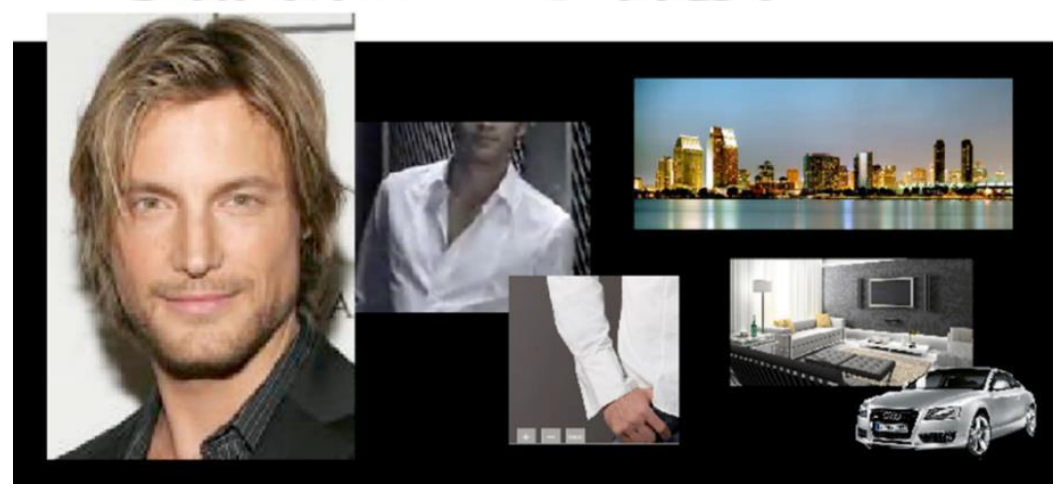




\section{Evaluación cuantitativa Home Use Test (HUT):}

- 3 aromas candidatos finalistas candidatos: My Desire, Black Portfolio, Liquid Leather más la competencia Temptation de Unique/ Yanbal

- Concepto y Board de imágenes.

\section{Evaluación técnica de duración:}

- 3 aromas candidatos versus Temptation

\subsection{Etapa 4: Evaluación con consumidor - Aprobación prototipo}

Como resultado de las evaluaciones con consumidor, se ajustaron los estímulos presentados y se aprobaron los siguientes elementos en Puerta - Gate 5 o presentación de Prototipo:

\subsubsection{Concepto y Key Brand Benefit (KBB):}

Se eliminó el término "carismático" considerado como "irrelevante" quedando como KBB: con Pulso de Ésika me siento un seductor irresistible como Christian Meier. Valores a transmitir: Sensualidad Irresistible

\section{Figura 1.7}

Concepto aprobado

El posee un poder de seducción innato que le permite conquistar a cualquier mujer con su mirada penetrante y su media sonrisa.

Es increíblemente atractivo e interesante. Un hombre fascinante que disfruta de la vida y valora su libertad.

Auténtico, seguro de sí mismo, simplemente...irresistible

\subsubsection{Concept Board:}

El modelo aunque guapo, pero desconocido no convence. Su tipo anglosajón y cabello rubio no es bien recibido por verse desordenado y poco seductor. Falta el look latino. Se constata 
que es necesario contar con un personaje reconocido para hacer más creíble la historia la cual sí constituye un concepto deseable y con alta intención de compra.

Figura 1.8

Board aprobado

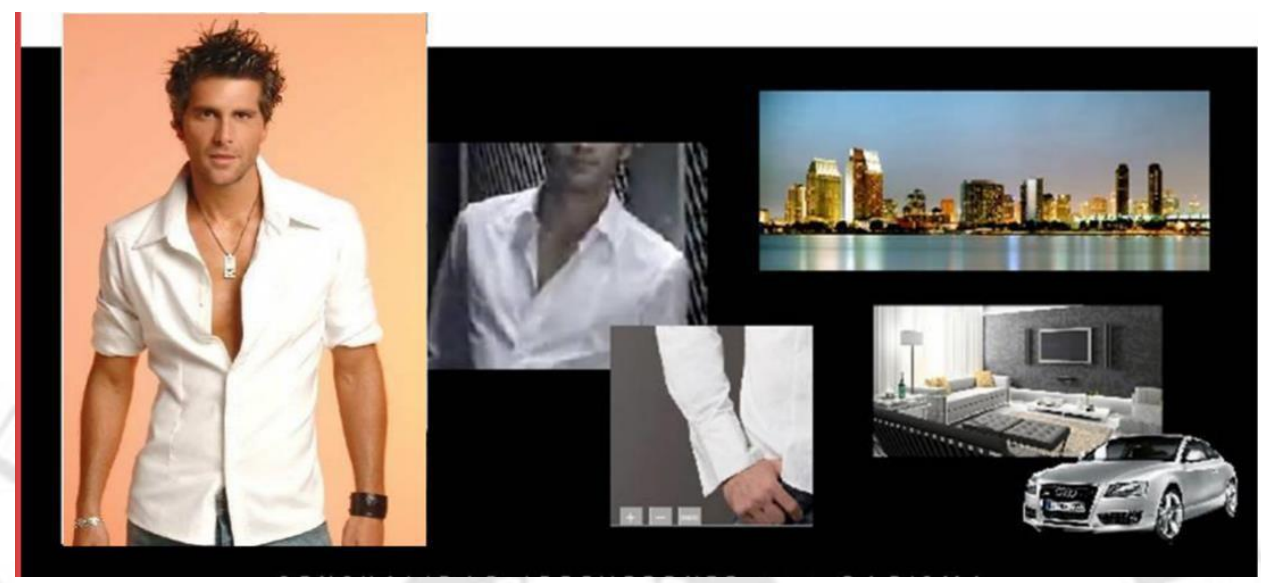

Nota: El estudio de celebrity se hizo en paralelo eligiéndose a Christian Meier

\subsubsection{Envase ganador: diseño industrial, gráfico, nombre.}

Forma: alta, piramidal en negro traslúcido: transmite elegancia, virilidad, imponente, superior a los demás, exitoso, seductor, de alta calidad y duración. Si el color es totalmente sólido se duda de su calidad.

Las letras rojas fueron las preferidas al ser un color con el que el hombre se identifica mucho y lo asocia a objetos deseables como auto, navaja suiza, ropa interior sexy, manzana tentadora, labios rojos...La firma de Christian Meier fue añadida posteriormente.

La caja seleccionada fue preferida por su sencillez apuntando a ser un "backing" para el envase que es el protagonista.

El nombre elegido fue Pulso: nombre corto, transmite masculinidad, seguridad y elegancia, fácil de recordar y pronunciar. 
Figura 1.9

Diseño de envase ganador Pulso.
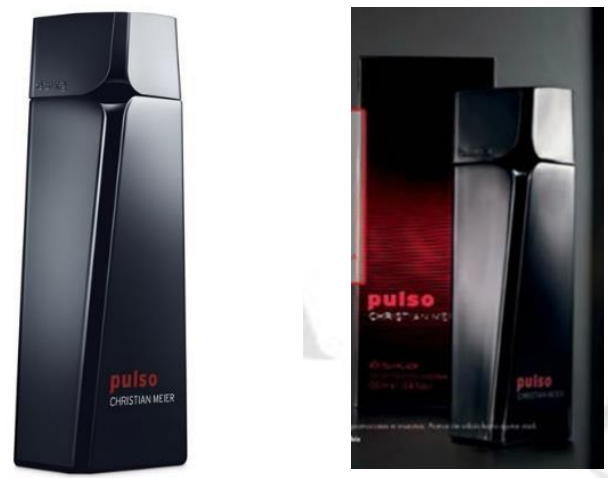

\subsubsection{Fragancia}

La fragancia seleccionada para Pulso fue "Black Portfolio" creada por la perfumista francesa Fabienne Coupaye (Anexo 5) de la Casa Symrise. Christian Meier participó en la elección y ajustes de la fragancia para incrementarle intensidad lográndose un aroma que transmite los valores del concepto y a la vez gusta auténticamente al artista. El aroma ganador pertenece a la familia Fougere Oriental Woody con esta descripción y pirámide olfativa...

Figura 1.10

Pirámide olfativa de Pulso de la familia Fougere Oriental Woody e inspiración de la perfumista.

Una fragancia cálida, envolvente, inolvidable para un hombre seductor, irresistible

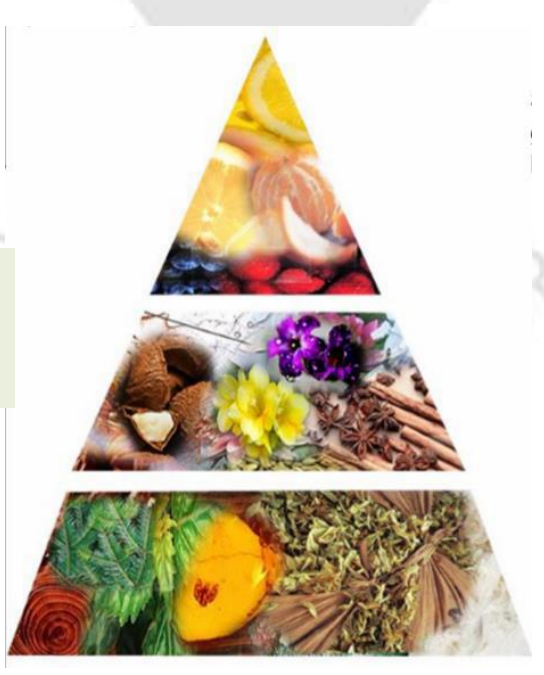

SALIDA: sambuca, grosella roja, cardamomo, limón, raíz de angélica

CUERPO: nuez moscada, acorde de frutas secas, badiana, anís estrella, fresia, heliotropo

FONDO: bálsamo de Perú, hojas de tabaco, cedro rojo, cashmere, ámbar 
Fabienne Coupaye (2009) nos contó personalmente su inspiración para crear este aroma:

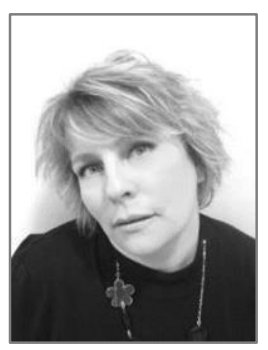

Para crear la fragancia del Hombre Irresistible tengo que reconocer que sólo dejé correr mi imaginación... Un hombre sexy, de sonrisa enigmática y mirada llena de seducción. Carismático y encantador, irreverente y fascinante, elegancia natural y sin complicaciones. Un hombre que me derrite, sólo con mirarme intensamente.

Este gate contó con la aprobación de la Directora de Ésika y Presidencia de Belcorp dado que se consideró como proyecto con prioridad estratégica A.

\subsection{Lanzamiento}

Siendo la primera vez que Ésika tenía una campaña de publicidad para una fragancia masculina, el objetivo fue lograr sorprender y lograr el mayor impacto en alcance y fuerza del mensaje.

La campaña se planteó como una estrategia de comunicación integral a nivel masivo y a fuerza de ventas para así lograr alcanzar al consumidor final, a los clientes y a la fuerza de ventas a través de una comunicación con mensajes alineados entre el plan de medios masivo, el catálogo de ventas y el plan de relaciones públicas.

\subsubsection{Estrategia de medios a Cliente y Consumidor}

\section{Televisión:}

El comercial de TV fue la columna vertebral de la campaña y debía comunicar los valores de Seducción Irresistible a través de imágenes que evidenciaran las características de este hombre, las cuales habíamos identificado en el estudio cualitativo inicial en hombres y en mujeres. El storytelling del comercial gira alrededor del personaje principal, un actor de telenovela como es Christian Meier en un mundo sofisticado que le es natural a él. Christian es además naturalmente seductor, sumamente atractivo y de tipo latino, lo cual aporta credibilidad, deseabilidad y motivación en el consumidor.

Para cumplir con este reto, la agencia J Walter Thompson creó un comercial que incluyó códigos aprendidos en los estudios con consumidor para transmitir de manera 
convincente el beneficio emocional de seducción irresistible. De esta manera el guion del spot reforzó la elegancia, el status, caballerosidad, presencia de piel, cuerpo en forma, mirada penetrante y actitud segura. Un experimentado director como Claudio Droguett y un actor harían posible transmitir el imaginario de la seducción irresistible en la ejecución de un spot de TV de sólo 20 segundos. El fondo musical sensual complementó el mensaje con un audio invitador: "Descubre qué es lo que lo hace irresistible, Pulso de Christian Meier la nueva fragancia de Ésika”.

El comercial comunicó con claridad pocos mensajes clave:

1. Es una fragancia de Christian Meier, no es que él simplemente sea un modelo para una nueva fragancia, sino que ésta lleva su nombre, él la usa, él la creó.

2. Es una nueva fragancia

3. Es de Ésika

4. Es seductora, irresistible

Figura 1.11

Ficha de comercial TV Pulso https://www.youtube.com/watch?v=8ExH2WJ_8eM

\begin{tabular}{|ll}
\hline Ficha resumen de producción Pulso \\
$\begin{array}{ll}\text { Agencia de Publicidad } & \text { J.Walter Tompson, Perú } \\
\text { Central de Medios } & \text { Starcom, Perú } \\
\text { Dirección y Producción } & \text { Claudio Droguett, Twist Films, Chile } \\
\text { Locación de Filmación } & \text { Buenos Aires, Argentina }\end{array}$
\end{tabular}

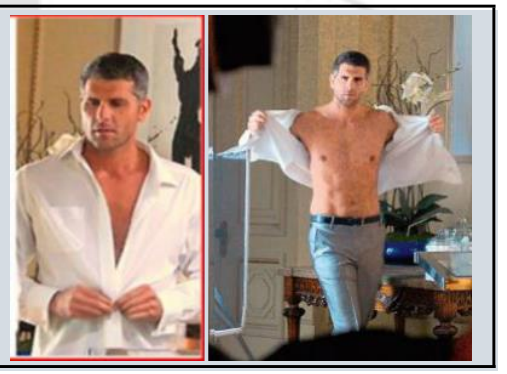

Nota: Se incluye este comercial y los de las siguientes versiones en el CD que acompaña la monografía.

La pauta de TV consideró canales nacionales de señal abierta y cable en Perú, Colombia, Bolivia, Chile, Venezuela, Guatemala y El Salvador. Se priorizaron canales de cable con llegada a Latinoamérica como Sony, TNT, E, AXN. TNT desarrolló proactivamente un video promocional el cual se adjunta en el CD de este trabajo.

\section{Vía Pública:}

Los medios seleccionados $\mathrm{OOH}$ fueron paneles en zonas de alto tránsito en los principales países de Ésika como Perú, Colombia, Bolivia y Venezuela. 
Figura 1.12

Paneles vía pública
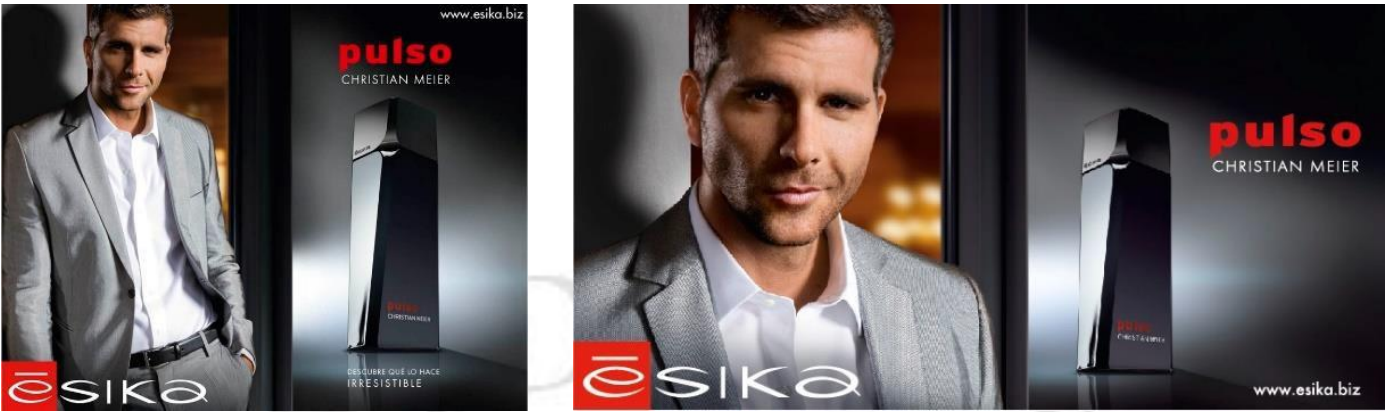

\section{Revista:}

La sesión fotográfica para revista, catálogo e impresos en general se hizo terminada la filmación lo que ayudó a que los medios impresos hicieran sinergia de manera integral con la TV reforzando los mensajes de Seducción Irresistible, Christian Meier y la marca Ésika. Las revistas seleccionadas fueron Somos y Cosas en Perú y equivalentes en otros países como Carrusel en Colombia.

Figura 1.13

Aviso Revista

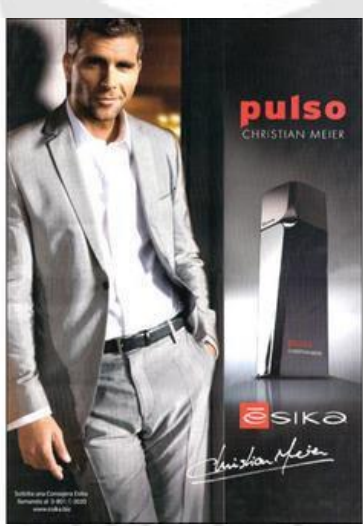

\section{Estrategia Digital:}

Se utilizó la página Web de Ésika donde se compartió el comercial de TV y el Make of del mismo. Además se incluyó un juego interactivo en el que se debía encontrar la fragancia Pulso escondida en el Hotel, escenario del comercial. 
Figura 1.14

Juego interactivo para página web: https://www.youtube.com/watch?v=285xOoBWV7A

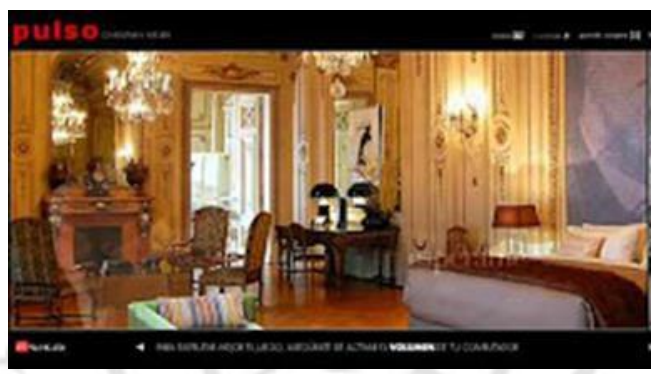

\subsubsection{Estrategia a Fuerza de Ventas}

La campaña hacia fuerza de ventas integró el medio catálogo con muestreo y actividades de incentivo y eventos especiales que motivaron a las miles de consultoras a promocionar la nueva fragancia de manera apasionada y convincente. El medio tradicional Catálogo tuvo una comunicación innovadora para una fragancia masculina incluyendo carátula y 2 páginas dobles con muestra para oler el aroma de Pulso. El pauteo de la fragancia Pulso fue al 100\% en las siguientes 18 campañas.

Figura 1.15

Páginas de Catálogo Lanzamiento y Mantenimiento

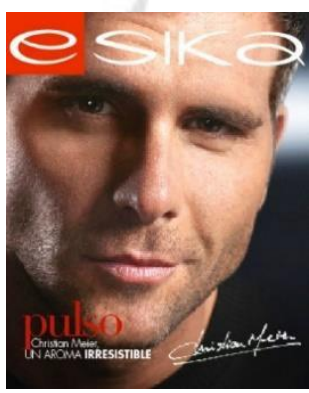

Carátula

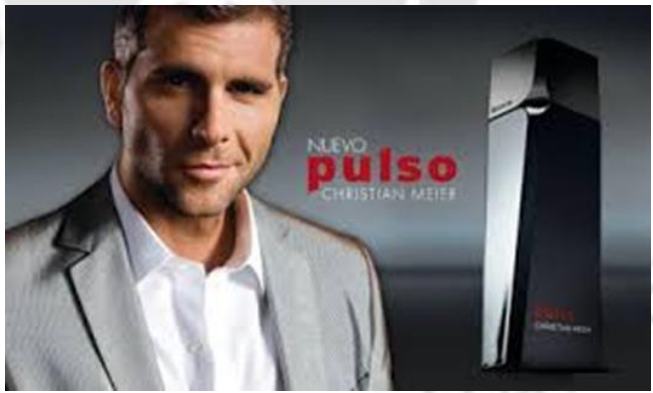

Primera doble página

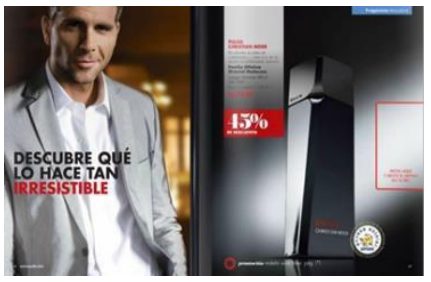

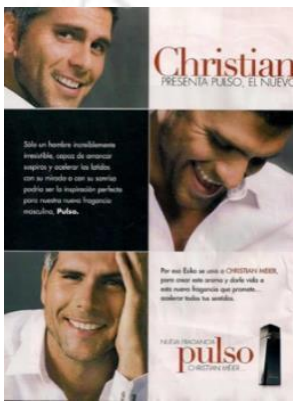

Segunda doble página

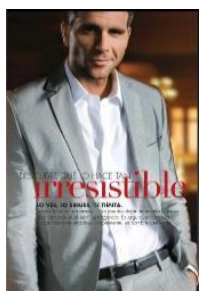

Otras páginas de siguientes campañas 
- Muestreo con Selling Cards: son postales impresas con una imagen de la campaña y un sachet de $0,9 \mathrm{ml}$ con la fragancia pegado en la retira. Este muestreo llegó a todas las consultoras para impulsar la prueba de producto así lograr la venta final.

- Concurso de ventas: con incentivos que incluyeron productos propios Ésika, e innovando con almuerzos, cenas y "días” con Christian Meier al lograr metas de ventas. https://www.youtube.com/watch?v=yra8IOMT-AE

- Afiches de Christian Meier: distribuidos a las Consultoras que asistieron a las Conferencias de ventas y eventos.

Figura 1.16

Afiche para Fuerzas de Ventas
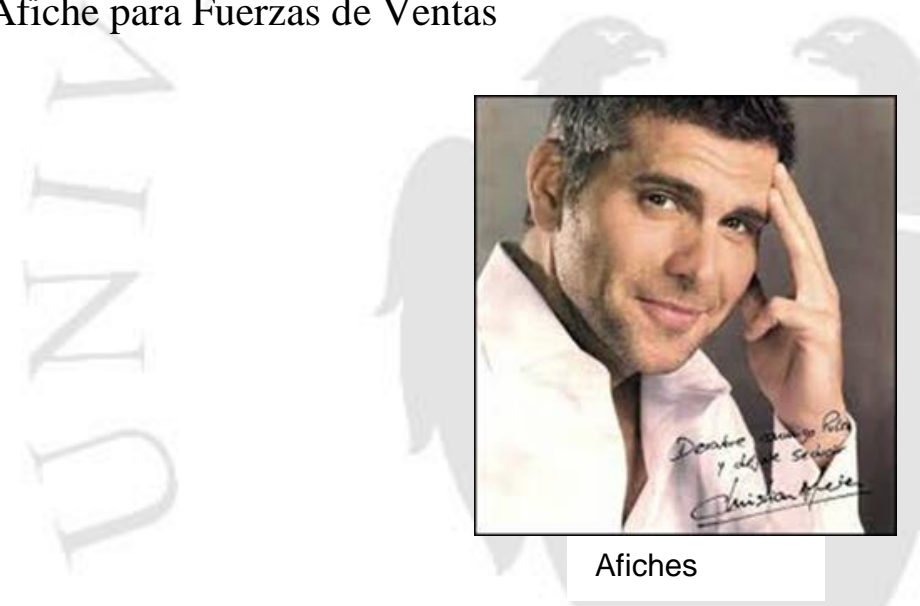

- Evento de Lanzamiento con presencia de Christian Meier en hoteles 5 estrellas de Perú, Colombia, Bolivia, Chile, Guatemala, El Salvador con un promedio entre quinientas a mil quinientas consultoras por evento que se divirtieron y salieron con mucho optimismo. En el evento se transmitió el comercial, el Make of y un video de la creación de la fragancia con participación de la perfumista. 
Figura 1.17

Material motivador de evento Lanzamiento para Consultoras

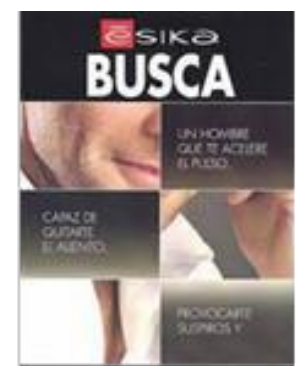

Invitación a consultoras

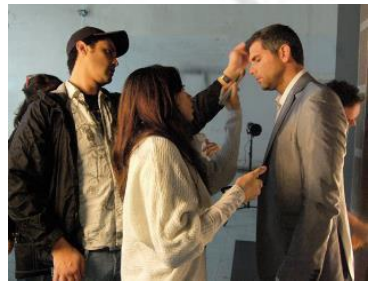

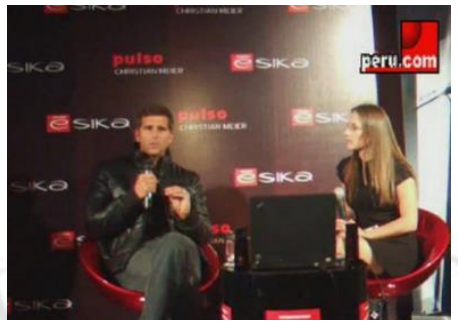

Evento a prensa Lima https://youtu.be/ZVpvRn8HjR8

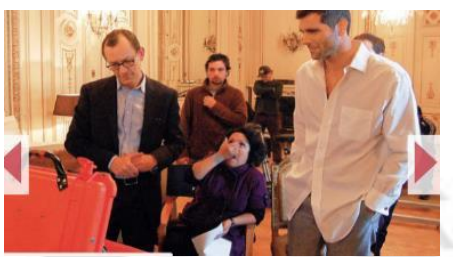

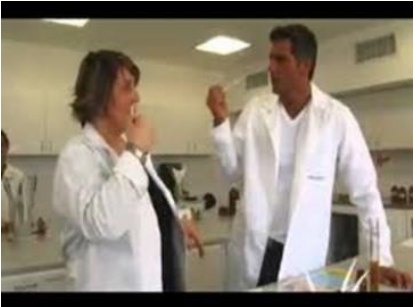

Video a FFVV

https://youtu.be/f8FGkCmNOHs

Making of de spot TV

https://youtu.be/VoHNdd-IG2w

\subsubsection{Estrategia de Relaciones Públicas}

Se convocó a conferencias de prensa y entrevistas One on One con diferentes medios de TV, revistas, diarios e internet con amplia difusión en la mayoría de medios de Perú, Colombia, Bolivia, Venezuela, Ecuador y Chile. Christian fue invitado a programas de TV donde además de entrevistarlo sobre su vida privada y artística se le preguntaba acerca de la fragancia como fue el caso de Baily en Perú y donde también tuvo imitaciones en programas como Carlos Álvarez. En otros países fue también altamente entrevistado en TV y prensa y se publicaron una serie de carátulas en revistas con Christian con el lanzamiento de Pulso. 
Figura 1.18

Cobertura de eventos de lanzamiento

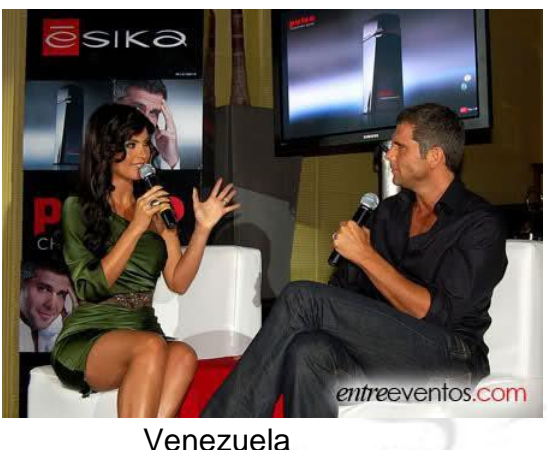

Venezuela

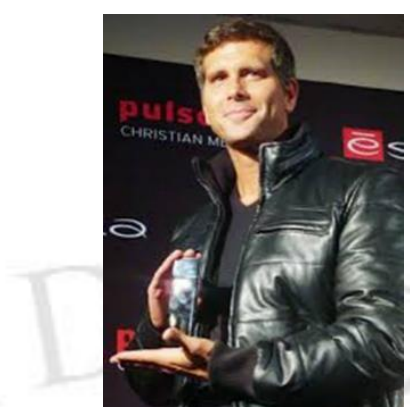

Ecuador

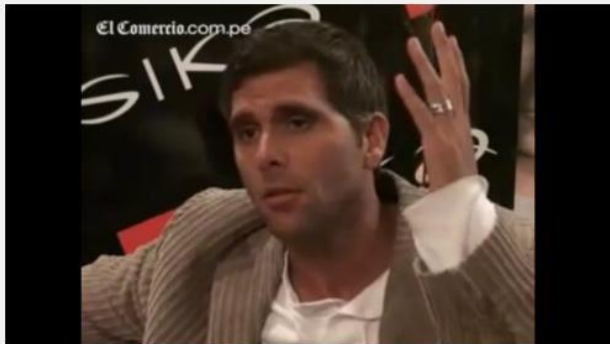

Perú https://www.youtube.com/watch?v=9eZLyBXGt1s

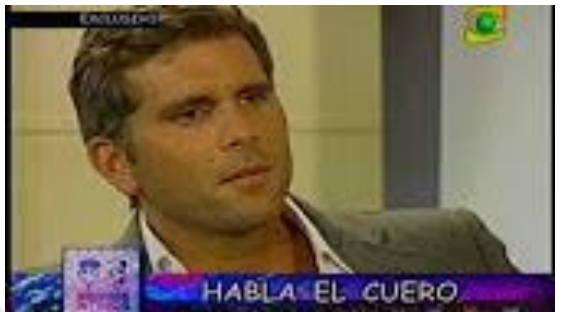

Perú: Entrevista Beto Ortiz en evento https://www.youtube.com/watch?v=nOE4D5LZmFE

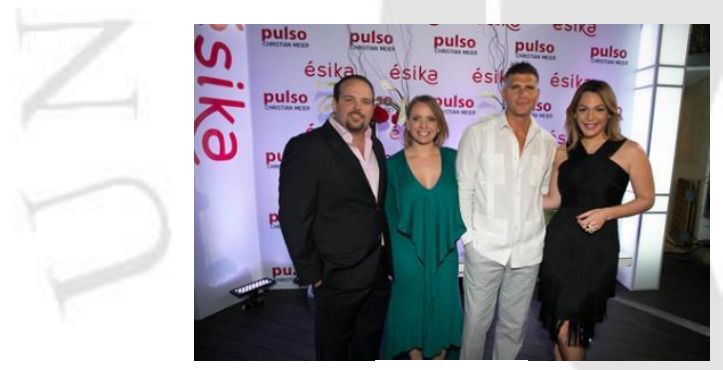

Bolivia

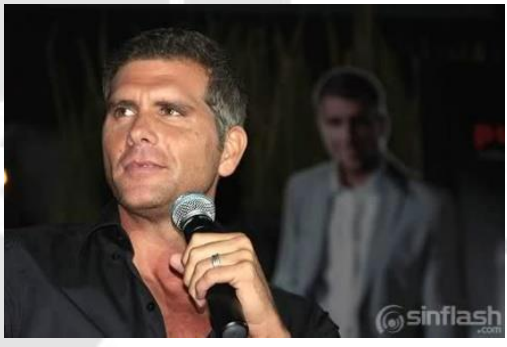

Chile

Figura 1.19

Rebote en carátulas de revistas

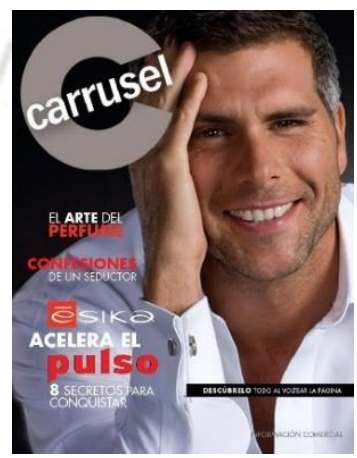

Carátula rebote en Revista Carrusel de Colombia 
La fragancia se lanzó posteriormente en otros países conforme el crecimiento de Esika y con actividades de cobertura de prensa, como es este ejemplo en Puerto Rico.

Figura 1.20

Cobertura lanzamiento nuevos países
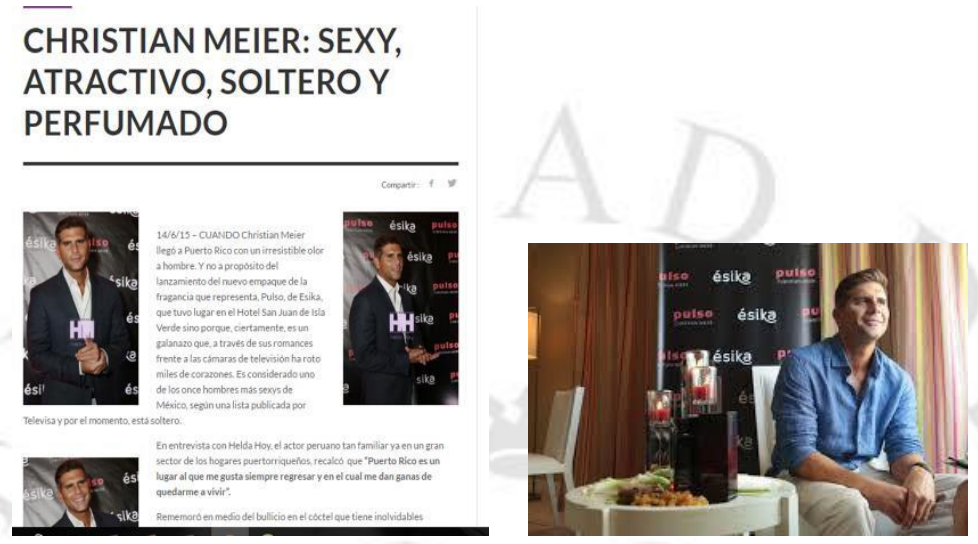

Puerto Rico https://www.youtube.com/watch?v=pzTgCaziHwA

\subsection{Post Lanzamiento: Resultados}

Los resultados del lanzamiento superaron en $15 \%$ los objetivos a nivel ventas y unidades. También se superaron las metas de participación de mercado en los principales países de la corporación: Perú y Colombia. Además, la campaña tuvo una intensa cobertura de prensa en los principales medios masivos escritos, TV y en digital durante 6 semanas. La cobertura incluyó parodias en programas cómicos como Carlos Álvarez. El impacto también fue positivo en recordación de marca y mejora de percepción de valor aportando en la construcción de Brand Equity de Ésika. A nivel relación con las consultoras, ellas se vieron respaldadas por una importante campaña de publicidad que favoreció la venta de un producto único, diferente al de la competencia y preferido por el público.

Los resultados más destacables son el haber logrado el 1er lugar en el ranking de fragancias en Perú y el 3ro en Colombia en el año 2009 con sólo 8 meses de venta, además de haber contribuido de manera sustancial en el incremento de porcentaje de ventas de Productos Nuevos sobre el total del portafolio de la categoría de fragancias finas de $23 \%$ a $31 \%$ representando un impacto del $33 \%$ en este indicador. 


\section{Tabla 1.1}

Resultados de Lanzamiento Pulso versus Objetivos

\begin{tabular}{|l|c|c|c|}
\hline \multicolumn{4}{|c|}{ Resultados de lanzamiento Pulso } \\
\hline \multicolumn{1}{|c|}{ Indicador } & Objetivos & Resultados & Resultados \\
\hline Ventas y Unidades & & $+15 \%$ & $+15 \%$ \\
\hline Share Colom bia & $3.2 \%$ & $3.6 \%$ & $+13 \%$ \\
\hline Share Perú & $3.0 \%$ & $4.0 \%$ & $+33 \%$ \\
\hline Pues to Ranking Perú & 3 & 1 & 1 \\
\hline Pues to Ranking Colom bia & 4 & 3 & 3 \\
\hline Peso Productos Nuevos & $23 \%$ & $31 \%$ & $+33 \%$ \\
\hline
\end{tabular}

Fuente: Data interna Ésika basada en información de ventas y participación de mercados medida por A\&S.

El éxito de la fragancia Pulso se ha mantenido a lo largo de los años lo que se fortaleció con el lanzamiento de 2 fragancias adicionales con el artista: Bravío en 2011 https://youtu.be/HOCPYOPx6gA y, luego Leyenda en el 2016 https://youtu.be/Lk7PMM_aUhk Pulso más Bravío de Christian Meier la convirtieron en la marca \#1 de ventas de Ésika. Hoy, en 2017, las 3 fragancias se comercializan evidenciando un largo ciclo de vida del producto frente al promedio de lanzamientos a nivel mundial con o sin celebrity. Cabe señalar que lo aprendido con el consumidor ha sido incluido en la continua construcción del concepto de Seducción Irresistible de las fragancias de Christian Meier de Ésika. 


\section{CAPÍTULO II: FUNDAMENTACION CONCEPTUAL}

\subsection{Importancia de Productos Nuevos}

Los productos nuevos son considerados para muchos estrategas de marketing como las principales armas para el éxito y prosperidad de las empresas En Estados Unidos representan un promedio del $28 \%$ de las ventas de las compañías de acuerdo al Product Development and Management Association (PDMA), aunque las empresas más exitosas alcanzan a un $38 \%$ de ventas derivadas de sus innovaciones (Cooper, 2011). En una multinacional peruana de alta Innovación como es Belcorp, las ventas de productos nuevos en el 2008 representaban no menos del 20\% (Data interna Belcorp) y esta empresa lo logra a través del lanzamiento de unos 150 productos nuevos al año (Belcorp.biz, 2016)). Belcorp dedica una alta inversión a la Innovación para lograr productos de alta calidad que cubran de manera única y convincente las necesidades no satisfechas de sus clientes y consumidores.

Como lo resumen Ulrich y Eppinger (2009): "El éxito económico de casi todas las empresas depende de su capacidad para identificar las necesidades de los clientes y rápidamente crear productos que satisfagan esas necesidades y se puedan producir a bajo costo" (p.2).

Para lograr este éxito empresarial, los productos nuevos deben también ser muy exitosos a nivel de ventas, rentabilidad y percepción de valor. Como lo indica el Doctor Cooper (2011): “el principal impulsor para que el nuevo producto sea rentable es un producto único, superior, diferenciado que entrega beneficios únicos y una propuesta de valor convincente al cliente o usuario" (p.32-traducido).

No basta con que técnicamente desarrollemos un producto mejor que el de la competencia, si esto no es percibido y valorado por el consumidor de poco servirá. Es el consumidor quien deberá percibir que el producto es superior a lo que la competencia ofrece en términos de calidad, valor por su dinero y beneficios claramente detectables.

Los productos nuevos bien desarrollados traen altos beneficios para las empresas y para el país. El impacto positivo en las empresas se ve en el crecimiento de mercado, 
revitalización de los portafolios de productos, mejora de utilidades y ventas, mayor conocimiento del consumidor y mejora de imagen de la marca, entre otros. El país se beneficia con avances de investigación, tecnología, mejor balanza comercial e imagen del país (Lerma Kirchner, 2010, p.4).

Y es justamente la Innovación a nivel productos, servicios y tecnología la que puede traer a nuestro país más bonanza económica que depender de nuestros recursos naturales. El desarrollo de productos nuevos puede impulsar la investigación y así llegar a un mayor número de patentes que nos permitan avanzar en nuestro nivel de competitividad mundial Hoy Perú ocupa el puesto 71 del ranking de innovación mundial según la Organización Mundial de Propiedad Intelectual (OMPI, 2016). Como lo resume Andrés Oppenheimer, los países más exitosos no son los que tiene más petróleo o cobre, sino los que exportan productos con mayor valor agregado (Oppenheimer, 2015).

\subsection{Evaluación previa al inicio del diseño de la fragancia}

El lanzamiento de la fragancia Pulso contó con un amplio y profundo trabajo de investigación a nivel de mercado y de consumidor a lo largo de todo el proyecto, desde la evaluación inicial para la detección de la oportunidad, pasando por todo el diseño del producto. Según McDaniel y Gates (2015) "la investigación de mercados es la herramienta primaria para explorar nuevas oportunidades en el mercado. La investigación de segmentación y la investigación de nuevos productos ayudan a identificar las oportunidades más lucrativas para la empresa." (p.15)

\subsubsection{Evaluación de Mercado}

En la etapa inicial de descubrimiento en el 2007 se realizó un análisis de negocio para detectar la oportunidad de mercado de una nueva fragancia fina masculina para Ésika.

Se observó que mientras que el mercado total de Cosméticos en Latino América era de US\$ 40 Bn según Euromonitor (2008), la Venta Directa representaba el 27\%, con Fragancias como la categoría más relevante con 30\%, seguida por Maquillaje con 19\%. Cabe 
señalar que al interior del mercado de fragancias, el peso de la VD representaba el 58\% de las ventas versus $42 \%$ para el canal retail.

Figura 2.1

Distribución por categoría en venta directa cosmética Latam.

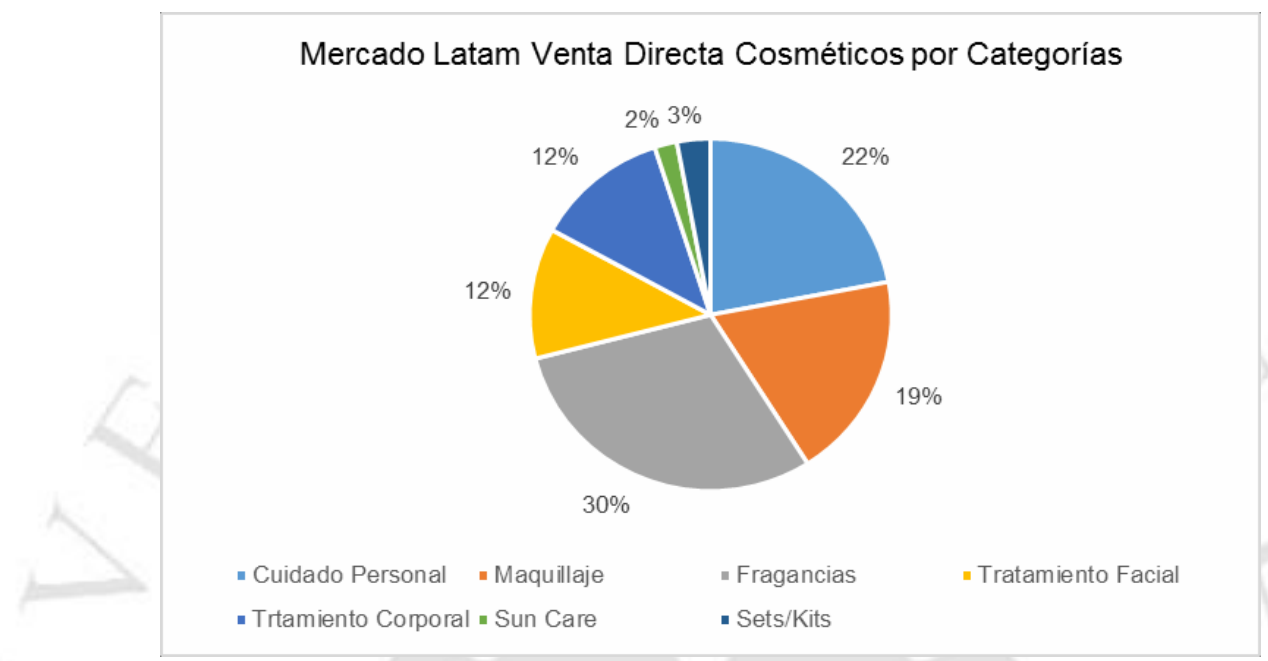

Fuente: Euromonitor (2008) en http://www.euromonitor.com/beauty-and-personal-care

Una amenaza para la Venta Directa y por lo tanto para la expansión de Ésika es el constante crecimiento del canal de distribución retail. Por ejemplo, en Perú, como lo explica Pipoli (en Mayorga Gutiérrez, 2012), "De acuerdo con la Asociación de Centros Comerciales y de Entretenimiento del Perú (ACCEP), existe un constante crecimiento del sector retail del país, revelado con las ventas brutas en los centros comerciales, las cuales pasaron de US\$1,760 millones en el 2007 a US\$ 3,213 millones en el 2010.” (p.111)

En ese sentido, las fragancias de marcas como Boss, Carolina Herrera lideraban en retail siendo muy valoradas por los clientes que cada día tenían más facilidades para adquirirlas con el acceso a tarjetas de crédito. Ante esta amenaza se vuelve más necesario el incremento de percepción de valor de las fragancias Ésika que por ser de Venta Directa tienen una tendencia a tener un menor Brand Equity.

Los mercados de mayores ventas de Ésika eran: Colombia (33\%), Venezuela (18\%) y Perú (18\%) y, como mercados de potencial crecimiento, Chile y Ecuador. Si bien México es una economía más fuerte que los países mencionados, Ésika tenía dificultad en 
conquistarlo y L’BEL sí tenía llegada. Colombia y Perú por lo tanto fueron seleccionados como prioritarios dados los obstáculos político-comerciales de Venezuela.

Figura 2.2

Distribución de ventas Ésika por países.

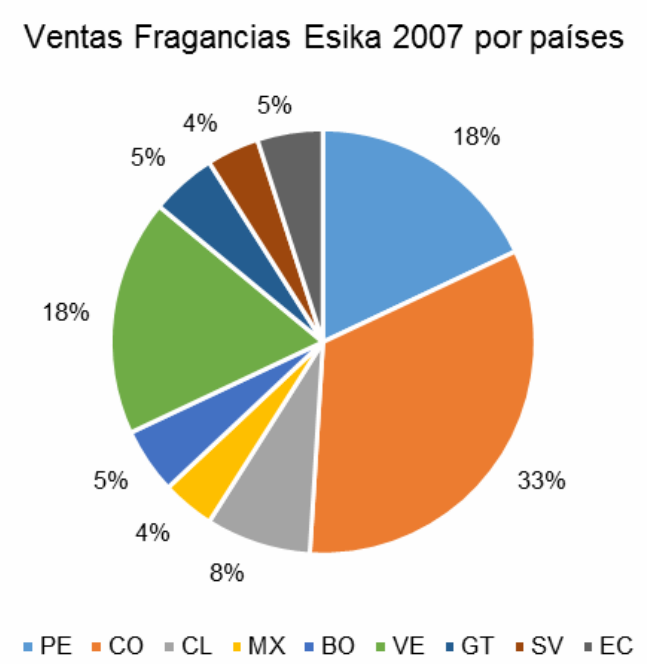

Fuente: Data interna Ésika

Siendo fragancias la principal categoría de Venta Directa en Latino América, se analizó el potencial de ventas de fragancias masculinas versus femeninas, viéndose que el mercado de las masculinas en Colombia y Perú es mayor que el de femeninas, tendencia que es apalancada por la venta interna de Ésika como líder del mercado (Anexo 6).

Teniendo en cuenta que Ésika lideraba largamente las preferencias de mercado en fragancias masculinas se vio como oportunidad el enfocarse en este tipo para ayudar en la construcción de Brand Equity vía el lanzamiento un producto de alto valor para el cliente y consumidor como sería una innovadora fragancia masculina. A la par se continuaría el trabajo de diseñar y desarrollar fragancias femeninas de alta calidad. Además, la Venta Directa en estos países tiene un mayor peso que el promedio de Latino América llegando a estar por encima del $75 \%$ para el caso de fragancias masculinas, lo que lo convertía en un driver para el fortalecimiento de marca frente a la amenaza retail. 


\subsubsection{Evaluación ruta conceptual}

La ruta conceptual fue la Sensualidad Irresistible masculina explorándose los códigos que la transmite a hombres y mujeres de manera creíble y deseable.

Se realizó investigación cualitativa en Bogotá con metodología focus groups contando con 2 grupos de hombres y 2 de mujeres de edades de 25 a 45 años de estratos 3 y 4 equivalentes a medio y medio bajo de Perú, usuarios y compradores de Venta Directa. En esta etapa del proyecto se optó por investigación cualitativa para poder tener información más íntima de los usuarios y así tener material útil para la construcción del concepto y los códigos que transmiten Sensualidad Irresistible. Tal como lo establece Malhotra (2008), "La investigación cualitativa, en forma de sesiones de grupo y de entrevistas en profundidad individuales, se utiliza para descubrir cuáles sentimientos sensoriales son importantes para los clientes. Este tipo de sentimientos no pueden revelarse mediante la investigación cuantitativa." (p.142).

Durante las sesiones se aplicaron técnicas proyectivas para profundizar más en las motivaciones y creencias reales de los consumidores potenciales dado que preguntas directas podrían haberse recibido respuestas más políticamente correctas. Como Malhotra (2008) añade, “...la gente puede ser incapaz de dar respuestas precisas a preguntas que tocan su subconsciente. Los valores, los impulsos emocionales y las motivaciones que residen en el nivel subconsciente se disfrazan ante el mundo exterior, mediante la racionalización y las defensas del yo." (p.145)

De esta manera afloraron códigos que en algunos casos son casi cliché por los arquetipos que se han formado en nuestras mentes a lo largo de nuestras vidas como es el caso del arquetipo El Amante de Carl Jung que se manifiesta como romántico, seductor y elegante. Las marcas con este arquetipo de personalidad tienen como objetivo que el consumidor se sienta deseado. Así mismo aparecieron códigos más osados que pudieron ser interpretados para la comunicación de este concepto y otros que sirvieron de inspiración para las siguientes versiones de la fragancia.

Según Malhotra (2008):

Una técnica proyectiva es una forma de cuestionamiento no estructurada e indirecta que anima a los participantes a proyectar sus motivaciones, 
creencias, actitudes o sentimientos subyacentes con respecto a los temas de interés. En las técnicas proyectivas, se pide a los individuos que interpreten el comportamiento de otros, en vez de describir el comportamiento propio. Al interpretar la conducta de otros, los participantes proyectan de manera indirecta sus propias motivaciones, creencias, actitudes o sentimientos en la situación. (p.163)

El estudio se denominó Imaginarios relacionados a la Seducción Irresistible y se buscaron respuestas a la pregunta: “¿Qué es un hombre de irresistible seducción?”. Se evidenció que existen códigos diferenciales típicos y deseables asociados a la "Sensualidad Irresistible" muy similares en ambos targets: hombres y mujeres.

Códigos para las Mujeres: es un hombre elegante con actitud caballerosa, es muy atractivo y magnético, con sensualidad natural. Es un hombre fuerte y auténtico y es el dominante en la relación. Tiene un físico atlético, torso marcado, se ve piel bronceada, algo de desnudez. Su mirada es penetrante y tiene una sonrisa sutil. Provoca una admiración física que genera idealización.

Su aroma tiene musgos, maderas y humedad porque son los olores de los "instintos". El envase lo imaginan recto, tonos oscuros, cubo negro. Estos códigos se asocian a lo elegante y varonil. En cuanto a animales, el caballo es asociado a la seducción masculina.

Ellas tienen la fantasía de dejarse seducir por este hombre. Nombran como representante de estas facetas al actor colombiano Rafael Novoa y sienten que los galanes de telenovelas representan a este hombre seductor.

Códigos para los hombres: imágenes asociadas al lujo, elegancia, status alto, vestimenta elegante tipo terno. También son importantes la mirada y la actitud de fuerza, así como el atractivo físico y la piel lo que los hace magnéticos. Su mirada debe ser profunda, rostro varonil y actitud ganadora. El atractivo físico debe ser notorio, así como su magnetismo social y la fama. Este hombre tiene la seguridad de conquistar a las mujeres. La seducción incluye artículos de lujo como autos y relojes.

Hay una frustración en los hombres al no contar con este cuerpo atractivo y bien formado, signo de virilidad y fuerza que protege y atrae a las mujeres. Piensan que, si se cuenta con fama y artículos de lujo como autos, status, acceso a lugares sociales de lujo, se 
puede compensar el no tener un físico perfecto para conquistarla de manera fácil y lograr su sumisión; sin embargo, la actitud ganadora tiene que estar siempre presente.

El aroma debía tener notas de selva, bosque y maderas que transmitan seducción y elegancia. El envase debía ser alto, como rascacielos que simboliza el poder y masculinidad. La tapa cuadrada y el color negro es el más asociado al concepto. Y, en cuanto a animales también salió elegido el caballo como símbolo de seducción.

De lo investigado, se aplicaron ciertos códigos para construir de manera más convincente, persuasiva, creíble y memorable el concepto de seducción irresistible.

Teniendo tanta riqueza de información, fue posible seguir construyendo el beneficio emocional de Seducción Irresistible en la segunda versión de las fragancias "Bravío" con la presencia del caballo y manteniendo códigos de: Mirada penetrante, piel, torso bien formado, dominio. En la tercera versión "Leyenda" se continuó reforzando el concepto con códigos como: mirada, piel, torso, lugares y accesorios de lujo, caballerosidad, dominio.

\subsubsection{Evaluación de oportunidad olfativa}

Las fragancias se agrupan en "familias olfativas" según su composición. Las familias olfativas masculinas principales aplicadas por Belcorp son las Aromáticas, Maderosas y Orientales. A lo largo de los años, expertos internacionales en evaluación de fragancias de las Casas Perfumistas han podido estudiar las sensaciones que transmiten ciertas notas olfativas a los usuarios.

- Familia Aromática/Herbal/Fougere: sus notas transmiten energía y masculinidad a través de hierbas aromáticas como romero, musgos, lavanda y bergamota.

- Familia Maderosa: transmite calidez, elegancia y masculinidad con notas como cedro, sándalo, pachuli, vetiver o cuero.

- Familia Oriental: trae misterio y seducción con notas balsámicas como ámbar, vainilla y especies. 
Según el análisis interno del top 30 de los rankings de Bogotá y Lima, la familia olfativa masculina más importante era la aromática o fougere con casi el 50\% de participación mientras que le seguían la oriental y maderosa con una presencia de aproximadamente $25 \%$ cada una. Se observó que a nivel internacional la familia Aromática seguía manteniendo el liderazgo aunque con una tendencia de crecimiento de las notas de madera y orientales.

\subsection{Evaluación del prototipo con consumidor}

\subsubsection{Evaluación del Celebrity}

La elección del celebrity se hizo mediante investigación de mercados cualitativa con Focus Groups en Colombia y Perú con sesiones de hombres y otras de mujeres de niveles socio económico medio, medio bajo y bajo. Se hicieron más sesiones de grupo en Colombia por la proporción de tamaño de mercado en fragancias y en Ésika. Estos estudios fueron ejecutados por la Agencia in house de Belcorp A\&S.

Es vital la elección del celebrity correcto que transfiera valores positivos y credibilidad a la marca, el riesgo de la mala elección es alta como menciona Kevin Lane Keeler en Branding (2008) pues podría traer valor negativo en el futuro con su comportamiento o desviar mucho la atención hacia la celebridad opacando totalmente al producto:

“Así, vincular a la marca a una celebridad implica cierto grado de falta de control...muchos consumidores creen que las celebridades sólo están prestando su imagen a cambio de dinero, que no necesariamente creen en la marca que están respaldando y que ni siquiera la usan... Para superar estos problemas, los mercadólogos deben evaluar, seleccionar y utilizar de manera estratégica a las celebridades que serán sus portavoces." (p.307)

Se seleccionaron 3 celebrities candidatos, reconocidos en Latinoamérica. A continuación, una breve descripción de los artistas y los resultados de las sesiones:

- Alejandro Fernández: cantante mexicano de música principalmente ranchera y baladas. Ha sido premiado internacionalmente por su performance musical. Más que una celebridad latinoamericana fue asociado solamente a México aunque se reconoce su éxito, calidad como cantante y su físico atractivo. Quedó 3ero en la preferencia 
como estrella pues lo veían lejano y no lo conocían muy bien. Cabe señalar que en el estudio Pre Concepto se empezó a vislumbrar que la fantasía de este hombre seductor irresistible se ligaba más a un actor de telenovelas que a cantantes

- Rafael Novoa: actor de telenovelas y modelo colombiano, fue mencionado de manera espontánea en el estudio pre concepto y por su fama en Colombia se pensó que sería el ganador. La conclusión fue que era un actor muy reconocido por los colombianos y en menor lugar en Perú donde a diferencia de Colombia los hombres no ven muchas telenovelas. Es considerado muy atractivo y quedó en 2do lugar de preferencias incluso en Colombia. Posteriormente fue contratado por AVON para representar una fragancia, hoy descontinuada, sin mucho éxito

- Christian Meier: cantante, modelo y actor peruano, ha recibido varios premios por su carrera actoral así como reconocimientos de revistas como uno de los hombres más sexy de Latinoamérica por revistas como People, GQ, Cosmopolitan y canal Televisa. Fue sumamente admirado por hombres y mujeres entrevistados. Los hombres quisieran ser como él, lo consideran un gran profesional, sumamente guapo, a la vez que simpático y cercano. Les cae bien, no es soberbio. Para las mujeres es absolutamente guapo y sexy. Todos de acuerdo con que sea elegido para una fragancia. Las mujeres dicen que se imaginarán que sus parejas son Christian luego de echarse el perfume. Los hombres dicen que seguramente sus parejas los alucinan como Christian y por eso les compran la fragancia, pero no les importa.

El elegido fue Christian Meier quien aportó valor a la fragancia, además de un comportamiento comprometido con la marca, siendo real y orgulloso usuario de la fragancia. 
Figura 2.3

Artistas evaluados para el proyecto.

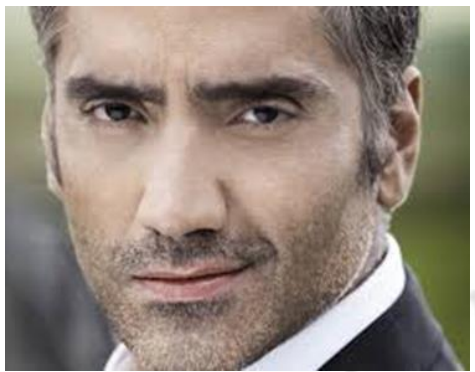

Alejandro Fernández

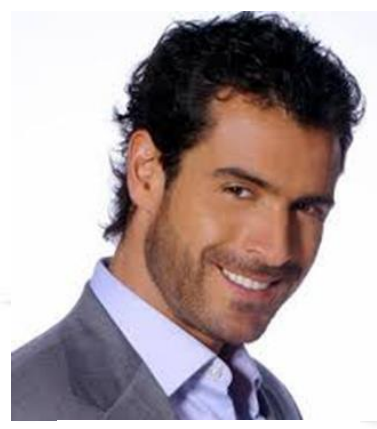

Rafael Novoa

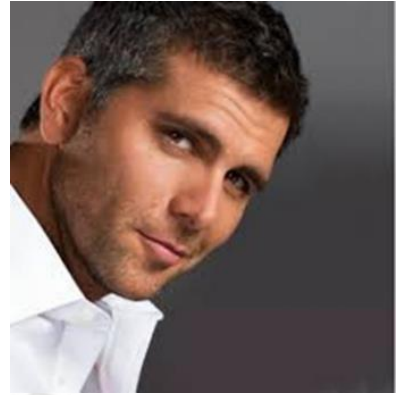

Christian Meier

\subsubsection{Evaluación cualitativa concepto, board, nombre v diseño.}

Para evaluar las propuestas de concepto, board y envases se priorizó el estudio cualitativo con Focus Groups de hombres y mujeres edades 25 a 45 años de n.s.e. medio, medio bajo y bajo en Bogotá y Lima. Los grupos de hombres fueron 4, más 2 grupos de mujeres en cada ciudad. Los estudios fueron liderados por la Agencia de Investigación in house A\&S de Belcorp con presencia de ejecutivos del proyecto tras el espejo para tener aprendizajes de primera mano con el consumidor y clientas.

El concepto presentado fue:

"El posee un poder de seducción innato que le permite conquistar a cualquier mujer a través de su mirada penetrante y su media sonrisa. Increíblemente atractivo e interesante. Es un hombre fascinante que disfruta de la vida y valora su libertad.

Es carismático, auténtico, seguro de sí mismo, simplemente...imposible de imitar"

El concepto fue bien recibido, describiendo a una fantasía de hombre en todos los grupos. El hombre debería ser muy atractivo en cuanto a rostro y cuerpo, elegante y poseedor de artículos de lujo. El término "carismático" no aportaba en la historia pues no se entendía bien y en todo caso no era relevante.

El board de imágenes no incluía un artista conocido para no sesgar las respuestas, sino un modelo internacional. Los grupos consideraron que sí reforzaba el concepto, sin embargo, el modelo debería tener un tipo latino, lo que lo haría más seductor y atractivo. 
En cuanto al diseño de envase se prefirió notablemente la propuesta alta, angular de tonos negros como había ya sido sugerido en el estudio pre-concepto. El envase transmite masculinidad, porte, imaginario de buen cuerpo y elegancia. El tono negro es asociado nuevamente a la seducción y elegancia y la traslucidez del frasco aportaba mayor calidad que si era un tono totalmente sólido que no dejaba ver el líquido de la fragancia. Las letras rojas daban fuerza y eran llamativas y fáciles de leer.

El nombre Pulso, aunque en un inicio los grupos quedaban pensativos, era asimilado positivamente conforme se repetía. Lo prefirieron frente a otras opciones por ser corto, fácil de pronunciar. Las mujeres lo relacionaban con que el "pulso" se acelera ante la presencia de este hombre. En Perú se expresaron algunas pocas asociaciones a un antiguo programa político de televisión, pero esto no impactaba negativamente, por el contrario ayudaba en la recordación del nombre.

\subsubsection{Evaluación cuantitativa fragancia, concepto y board.}

En paralelo, el concepto y board tuvieron evaluación cuantitativa complementaria junto con el test de fragancias para incrementar la efectividad. "En definitiva, toda la investigación de mercados se emprende para incrementar la efectividad de la toma de decisiones. La investigación cualitativa se combina con medidas cuantitativas para brindar una comprensión más completa de la demanda de consumo." (McDaniel y Gates, 2015, p.93)

El estudio cuantitativo Home Use Test (HUT) fue ejecutado por CINDAMER en Bogotá. Se contó con 3 desarrollos de la Casa Perfumista Symrise y el benchmark Temptation de Unique/Yanbal. El objetivo del estudio fue definir la alternativa más apropiada frente al bench y detectar ajustes si fuera necesario.

La muestra fue de hombres de 25 a 45 años de clases media baja y baja, usuarios de Venta Directa (30\%) y perfumes de marca $(70 \%)$, para contar con una vara más alta de exigencia de calidad pues uno de los objetivos era mejorar la percepción de calidad.

Se trabajó una técnica cuantitativa, a través de encuestas personales con cuestionarios estructurados en los lugares de residencia de las personas participantes. La metodología aplicada fue ROUND ROBIN en el cual cada persona evalúa dos de las cuatro alternativas 
disponibles y posteriormente, mediante tratamiento estadístico se define la alternativa ganadora. Para la ejecución del proyecto se requirió de tres visitas:

- Primera visita: determinación de hábitos y valoración de la marca actual; evaluación de las muestras en cintilla y entrega de la primera alternativa.

- Segunda visita (4 días después); valoración de los resultados logrados con la primera muestra y entrega de la segunda muestra

- Tercera visita (4 días después); valoración de los resultados logrados con la segunda muestra y comparativo entre las dos alternativas

Las muestras fueron entregadas sin identificación de marca, es decir las evaluaciones fueron "a ciegas" y previendo la deserción entre cada fase, en la primera etapa se hizo entrega de un $15 \%$ adicional de muestras. La muestra estadística fue de un total de 202 encuestas efectivas, con información completa en las tres visitas.

Evaluación de la Fragancia: de las 3 alternativas presentadas, las alternativas Black Portfolio y My Desire fueron las que contaron con mejores asociaciones en agrado e intención de compra frente al Benchmark. La fragancia My Desire tenía una fuerte asociación con uso "de día” al sentirse más fresca lo cual generaba agrado. Sin embargo, este atributo le restaba valor al producto puesto que la noche es el momento ideal para estar más elegante y seducir. La fragancia candidata denominada Black Portfolio fue finalmente seleccionada por los equipos de Belcorp y por Christian Meier ya que generaba mayores asociaciones al uso nocturno, sentirse atractivo, seductor y sofisticado.

Además de considerar los resultados estadísticos, Christian Meier también escogió Black Portfolio por ser su fragancia preferida y que realmente usaría, aunque solicitó incrementar la intensidad, lo cual se hizo. Estadísticamente también se vio una oportunidad de mejorar la intensidad y duración de la fragancia Black Portfolio lográndose un parity plus versus el Benchmark en pruebas técnicas de sustantividad a ciegas llevadas a cabo en los laboratorios de Belcorp con panel de jueces expertos.

En cuanto al concepto y Board, el estudio cuantitativo complementó los hallazgos del cualitativo reforzando el deseo por un producto asociado a la seducción y la intención de compra así lo evidenció; sin embargo, se encontró que los hombres evaluados pensaban que otras fragancias ofrecían este beneficio y que no lo sentían que era totalmente creíble. Esta 
conclusión mostró que se necesitaba algo adicional que incrementara la credibilidad como por ejemplo la presencia de un artista asociado a los valores del concepto. Cabe destacar que en este estudio tampoco se mostraba ni mencionaba al artista.

En conclusión la variedad de estudios cualitativos y cuantitativos permitió conocer a mayor profundidad al consumidor y entregarle un producto diferente que le otorgaba un beneficio emocional de su interés de manera superior a lo que la competencia ofrecía. Esta conexión con el consumidor ha permanecido vigente siendo reforzada por la comunicación de Pulso y por el lanzamiento de 2 productos adicionales con el mismo artista. 


\section{CAPÍTULO III: LECCIONES APRENDIDAS}

El principal aprendizaje fue el impacto que tiene el conocimiento y entendimiento de los insights de consumidor para poder crear conceptos, productos y comunicación que sea relevante y convincente. Aun cuando se conocía su valor, el conocimiento de las verdades del consumidor para este proyecto en particular, sorprendió en un inicio, pero al aplicarse en el producto y su comunicación gatilló una respuesta positiva y, al ser profundo, tiene una duración de relevancia larga en el tiempo por lo que puede ser aplicada a diversas campañas y extensiones de productos. Es muy importante contar con estudios de consumidor, cualitativos y cuantitativos desde antes de la creación de los productos y comunicación para que haya total coherencia de lo que entregamos al mercado con sus deseos ocultos.

Otro punto importante es hacer estudios para la selección de un celebrity pues es muy fácil equivocarse. Sin estudio, se hubiera seleccionado a cualquiera de los otros candidatos y no se hubiera tenido el éxito que se tuvo. Con un celebrity bien seleccionado se han podido desarrollar varios productos con él en vez de trabajar con varios artistas. Esto también ayuda en la coherencia de mensaje al consumidor generándole seguridad y confianza que se traduce en su preferencia y lealtad.

Un aprendizaje adicional es que un Key Brand Benefit emocional conecta con el consumidor a través de historias donde los códigos aprendidos deben ser repetidos para reforzar el valor de marca. En este caso son: la mirada, el cuerpo bien formado, presencia de piel, tipo latino, lugares y accesorios de lujo y como animal, el caballo. Analizando grandes marcas vemos que su publicidad repite ciertos códigos que no son visibles a un ojo no entrenado y se mantienen para reforzar la comunicación y construir su personalidad y Brand Equity

Aprendimos que los artistas masculinos incentivan más las ventas que las femeninas, aunque me duela esta afirmación. Luego del lanzamiento de esta fragancia se trabajaron proyectos con celebrities femeninas, sin embargo ellas no traen las ventas y valor de marca 
como un celebrity masculino. Esto ha sido evaluado internacionalmente y se sugiere que es por la mayor credibilidad que trae la presencia masculina aun en nuestras culturas.

Otro aprendizaje de trabajar con celebrities es que la mejor elección son los actores y no cantantes ni modelos. Los actores saben representar su personaje en todo momento, con naturalidad logrando cercanía y fascinación del público. Además, es más fácil la cobertura de medios pues son invitados a los programas de TV y se generan situaciones simpáticas o jocosas con ellos. Las TOP Models aún las muy famosas, no hablan mucho y es muy complicado trabajar con ellas por su necesidad de control total de su apariencia como herramienta de trabajo.

Cabe señalar que la selección de Christian Meier además trajo energía positiva al proyecto pues él se involucró y disfruta de éstos de manera sincera y sencilla. Esto ha sido percibido por la fuerza de ventas en todos los países donde él va y participa afectuosamente con ellas en los eventos. Es importante esa autenticidad.

$\mathrm{El}$ análisis financiero que implica trabajar un proyecto con un celebrity tiene que ser hecho con mucho cuidado ya que no sólo involucra el contrato sino viajes con managers y acompañantes, hoteles, y continuo desarrollo de eventos para tener rebote en medios gracias a la cobertura de prensa. 


\section{REFERENCIAS}

Belcorp (2016): http://www.belcorp.biz/

Belcorp (2010): Diagnóstico Fragancias Ésika- Documento interno

Cooper, R.G. (2011). Winning at New Products: Accelerating the Process from Idea to Launch. New York: Basic Books.

Edwards, M. (2016). Fragrances of the World. http://www.fragrantica.com/news/MichaelEdwards-Fragrances-of-the-World-2015-6431.html

Euromonitor (2008): http://www.euromonitor.com/beauty-and-personal-care

Infante, I. (2011). Belcorp: L'Bel, Ésika y Cyzone: Belleza que trasciende. Lima: El Comercio.

Lane Keller, K. (2008). BRANDING: Administración estratégica de la marca. México: Pearson.

Lerma Kirchner, A.E. (2010). Desarrollo de nuevos productos: Una visión integral. México D.F.: Cengage Learning Editores.

Little, Arthur D. (2016). Innovation Excellence Model. http://www.adlittle.com/

Malhotra, N. K. (2008) Investigación de Mercados. México: Pearson Educación.

Mayorga Gutiérrez, D. (Ed.). (2012). Las mejores prácticas del marketing Casos ganadores de los premios EFFIE Perú 2011. Lima: Universidad del Pacífico Lima.

McDaniel, C, y Gates, R. (2015). Investigación de Mercados. México: Cengage Learning Editores

OMPI (2016) Índice Mundial de Innovación de 2016 de la Organización Mundial de Propiedad Intelectual (Ompi), organismo de Naciones Unidas. http://www.wipo.int/edocs/pubdocs/en/wipo_pub_gii_2016-intro5.pdf

Oppenheimer, A. (2015). ¡Crear o Morir! La esperanza de América Latina y las 5 claves de la Innovación. Buenos Aires: Debate.

Ulrich, K.T. y Eppinger, S.D. (2009). Diseño y desarrollo de productos. México, D.F.: McGraw-Hill Companies. 
Vidwrizaga, R. (2016). Introducci6n a Ia Categoria Fragancias- Esct.12/a ck Perfomeria Be/corp. Lima (PPT)

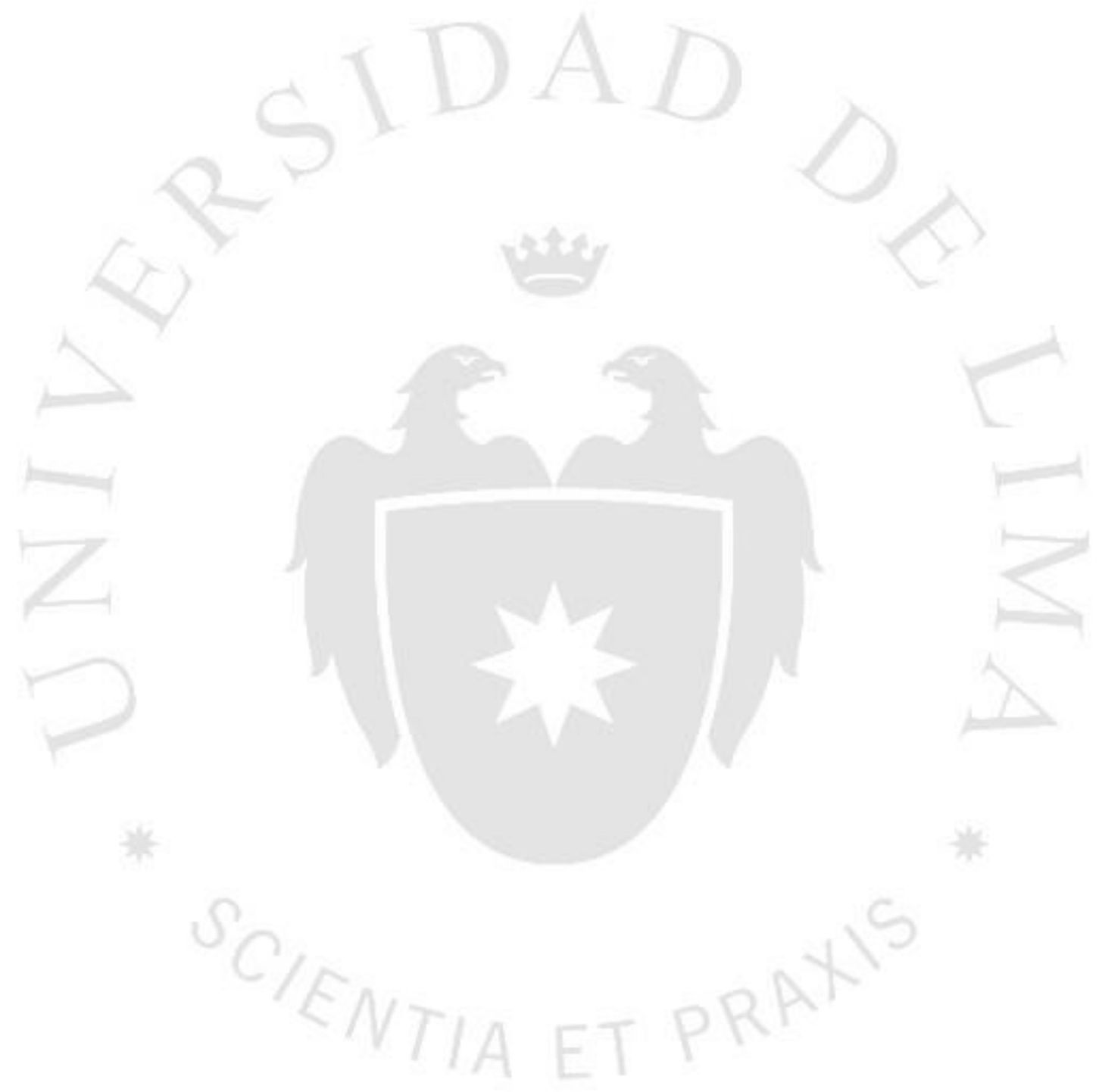




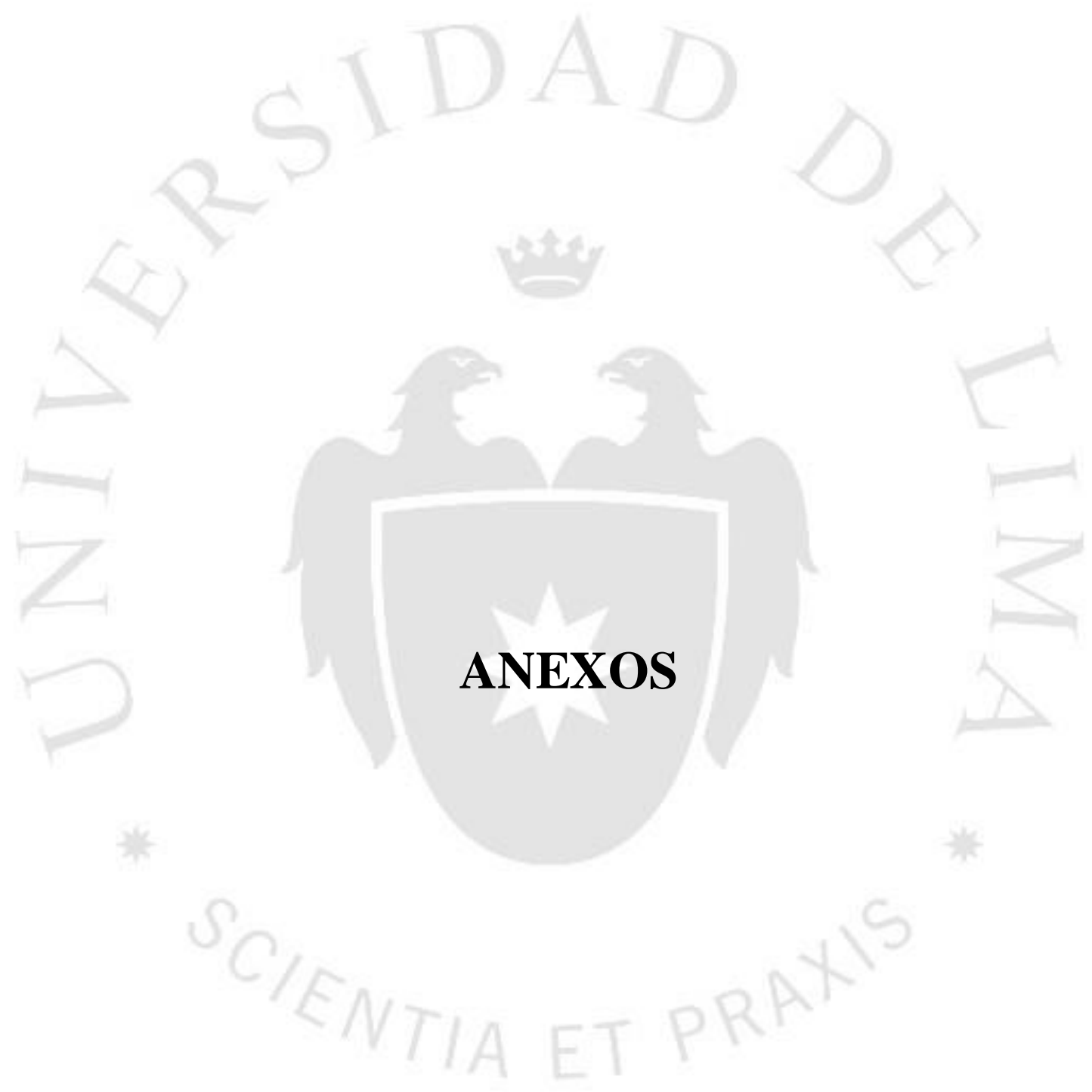




\section{ANEXO 1: El mundo de las Fragancias}

\section{Orígenes de la perfumería}

La palabra Perfume proviene del latín "per fummum” y significa: a través del humo, por el quemado de inciensos o aceites utilizados en la antigüedad para alabar a los dioses.

El rol del perfume evoluciona con la historia de la humanidad, con un origen sagrado y de lujo y que hoy también se asocia a la alta costura y a un estilo de vida.

\section{La pirámide olfativa o partes de la fragancia.}

Se habla que la perfumería es un arte como la música pues es una combinación de notas y acordes olfativos. También se relaciona con la pintura dado que el perfumista tiene una "paleta" con unos 1300 ingredientes disponibles para crear su obra.

Las fragancias ya elaboradas tienen 3 etapas en lo que se denomina la Pirámide Olfativa:

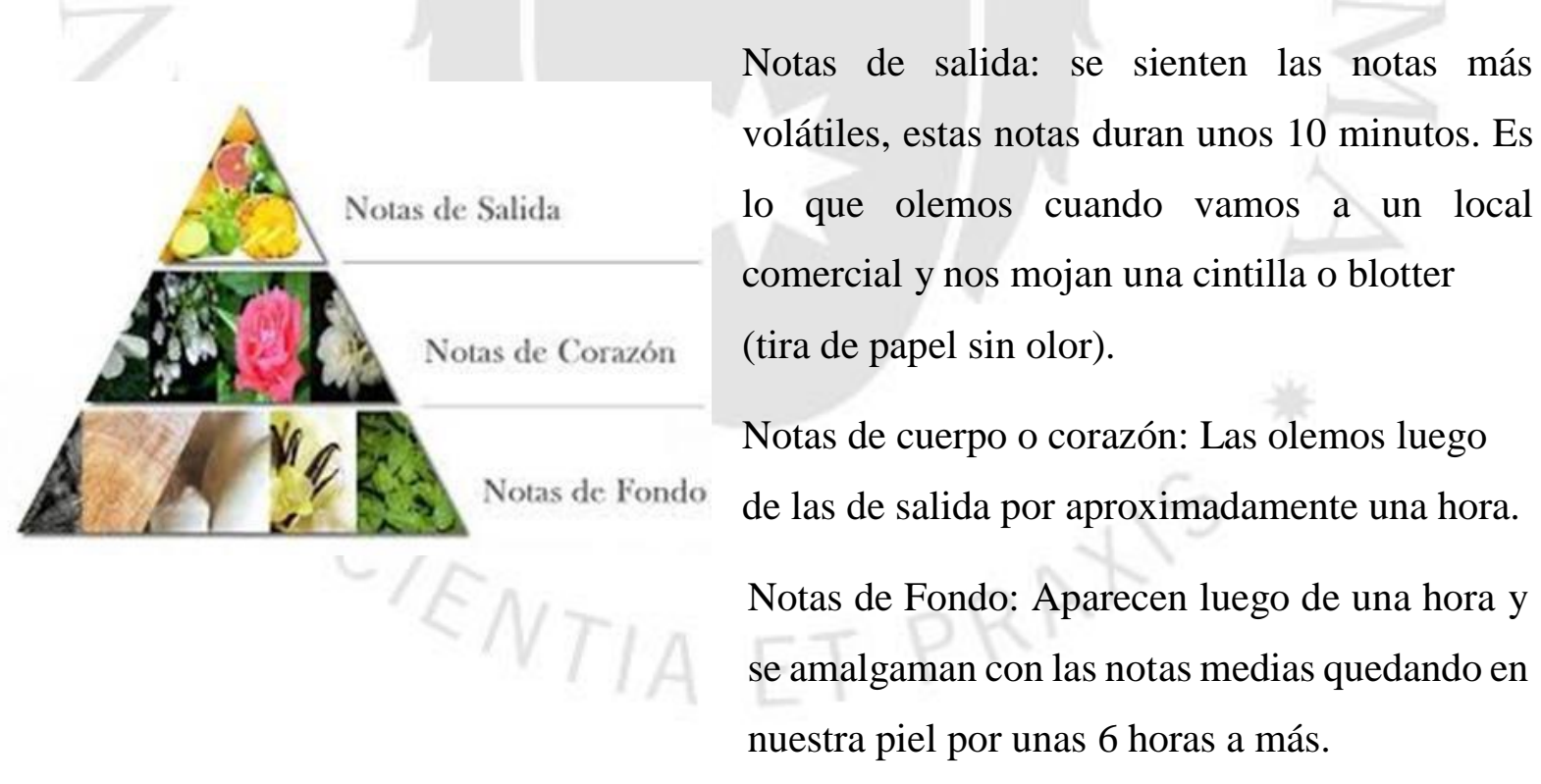

\section{Las Fragancias Finas y su relación con el consumidor}

Los aromas son capaces de evocar o generar sensaciones al transitar desde la nariz hasta el cerebro reptil. El olfato es un sentido muy primitivo, desde bebés nos ayuda a alimentarnos y reconocer a nuestros padres. 
Cuando olemos, la información de los aromas llega al sistema límbico y al hipotálamo, regiones cerebrales responsables de las emociones, sentimientos, instintos e impulsos donde también se almacena la memoria y regula la liberación de hormonas.

Por eso los olores pueden cambiar nuestro comportamiento, nos pueden relajar, excitar, energizar...

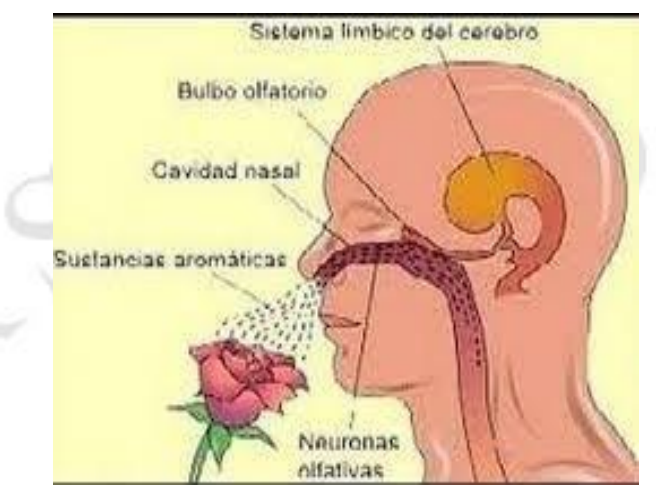

Cuando elegimos una fragancia ésta debe ser de nuestro agrado y cumplir con nuestras expectativas de duración, frescura, elegancia, modernidad, romanticismo, masculinidad, feminidad, sensualidad, etc. Estas percepciones se dan a través de las notas olfativas que transmiten distintos mensajes según las experiencias del target, su edad, la región, entre otros. Las propuestas y selección de los aromas desde marketing consideran un conocimiento profundo del consumidor y cliente. La fragancia además debe ser coherente con el concepto y el diseño del envase.

\section{El consumidor y la calidad (percepción y realidad) de las fragancias o perfumes}

El consumidor latinoamericano asocia la calidad o valor de una fragancia con la duración, mientras que técnicamente se habla de costos de perfumación. Un costo de perfumación alto implica el uso de ingredientes de mayor costo por ser naturales No existe siempre una directa proporcionalidad entre la duración de un aroma y el costo de perfumación pues depende también del estilo y materias primas escogidas por el perfumista. Sin embargo sabemos que los costos de fragancias como Chanel, Guerlain sí tienen costos de materias primas muy por encima de los aplicados en la venta directa, también los precios son por supuesto mucho más elevados. Las estructuras de costos de las fragancias Ésika asignan el 
mayor porcentaje posible a la perfumación para utilizar ingredientes de la mejor calidad. Asimismo durante el diseño de las fragancias se hacen pruebas de sustantividad o intensidad frente al benchmark seleccionado para garantizar que la nueva fragancia tenga igual o mayor intensidad a lo largo de los intervalos de medición. El peso del valor de marca sin embargo, impacta altamente en la percepción de duración de las fragancias así como también otras variables como el color del frasco, las notas de salida y el uso de celebrity. Finalmente como dijo Al Ries: Percepción es Realidad

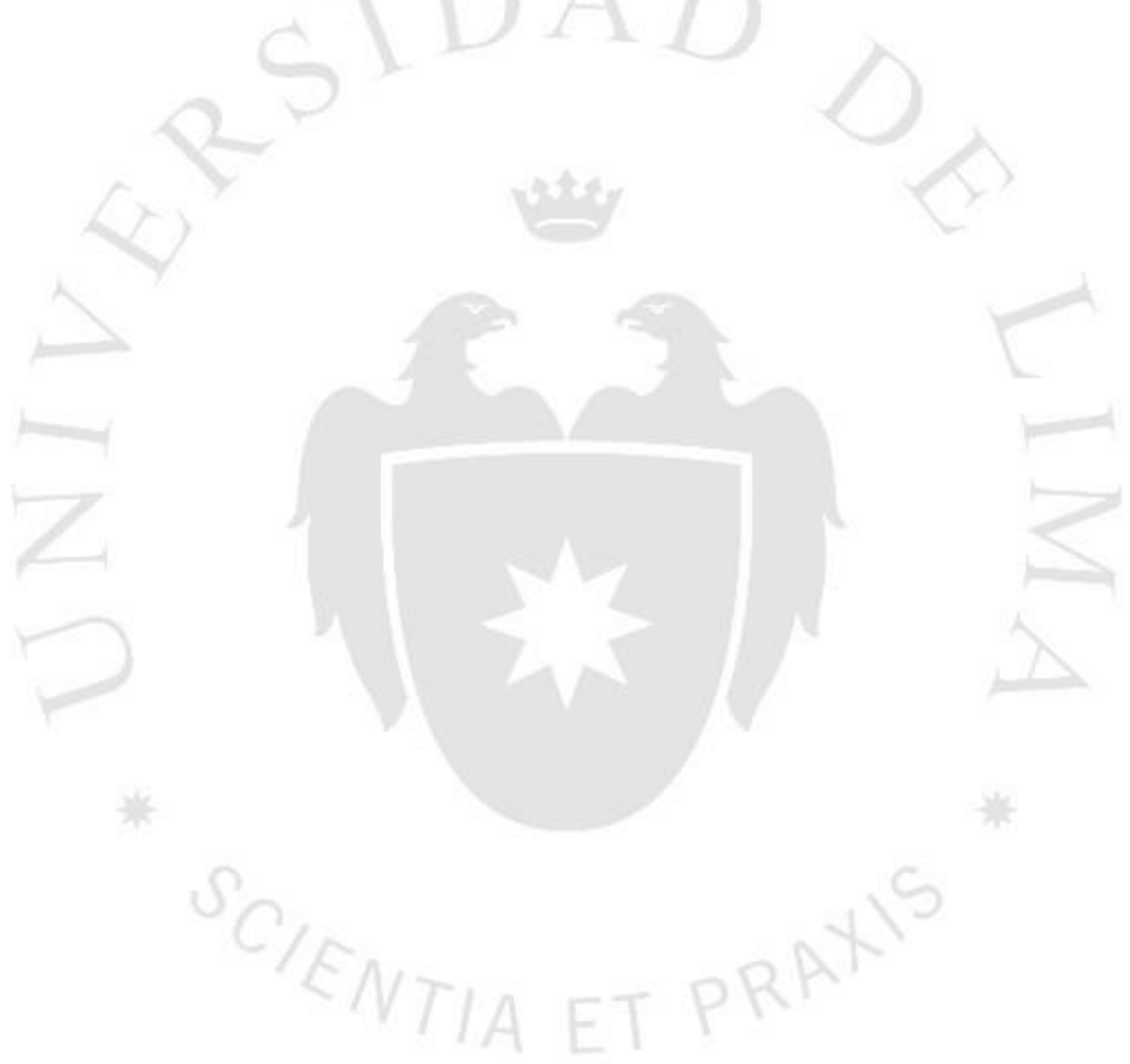




\section{ANEXO 2: Tendencias conceptuales analizadas para el proyecto}

Según los últimos lanzamientos de fragancias de grandes marcas internacionales y, en base a la experiencia de estudios anteriores y conocimiento del mercado, se analizaron 10 tendencias como posibles fuentes de rutas conceptuales para el proyecto. Estas tendencias fueron presentadas por las Casas Perfumistas Givaudan, Symrise, IFF, Firmenich

Tendencia Aventura: presenta al hombre redescubriendo la naturaleza, escape a lo verde con vestuario tipo explorador. Está solo, pensativo, transmite libertad e independencia. Ejemplos de esta tendencia son: Adventure de Davidoff, Polo Explorer de Ralph Lauren y Hilfiger. La tendencia se descarta para esta fragancia pues en estudios cualitativos anteriores con consumidor hemos visto que la mujer Ésika ve que ella no se ubica allí con el personaje. Ella siente que su hombre se va y la abandona. La ruta es interesante para los hombres y podría ser explorada para un Flanker o siguiente versión de la fragancia inicial. Este concepto además podría no transmitir suficiente elegancia para ser posicionado en un segmento alto de precio.

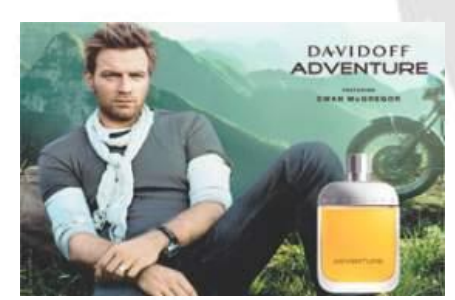

Adventure DAVIDOFF

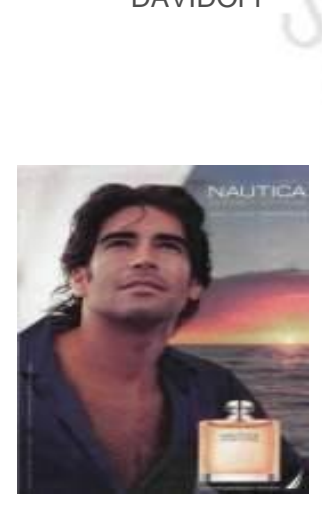

Sunset Voyage NAUTICA

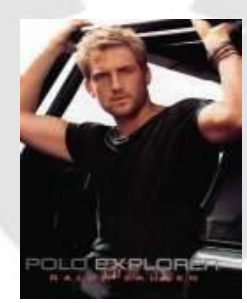

Polo Explorer RALPH LAUREN

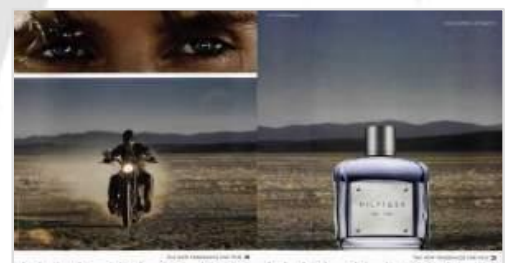

HILF I GER H I LF I GER

Hilfiger TOMMY HILFIGER 
sentirse cercana al consumidor. Otro riesgo es que la historia puede transmitir excesiva frescura de la fragancia y poca duración por las tomas abiertas.

Ediciones limitadas de verano: Son fragancias vibrantes, llenas de energía. El foco está en el diseño de los envases con mucha alegría y diversión, con conceptos superficiales y poco storytelling. La mayoría de estos lanzamientos son femeninos y juveniles y tienen corto ciclo de vida. Además, en algunos países de la región no se conoce el concepto de verano. Por lo expuesto, esta ruta fue descartada.

Tendencia Juegos de Seducción: Fragancias dúos para mujer y hombre, con química entre pareja, cuerpos que se atraen. Ej. Deseo for Men de Jennifer López, Unforgivable Black de Sean John. Habíamos visto por experiencias anteriores que las fragancias Dúo no traen altas ventas y el foco era una fragancia masculina.

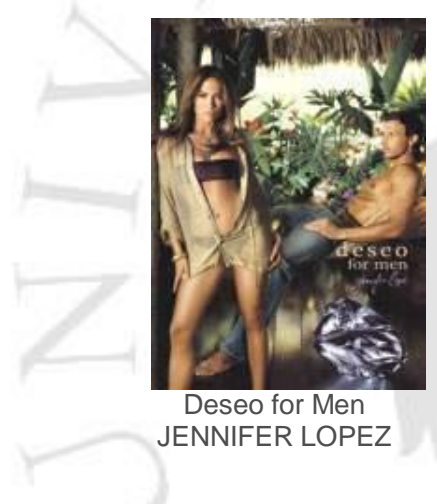

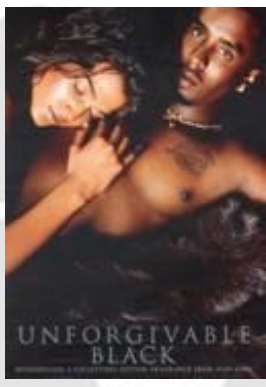

Unforgivable Black SEAN JOHN

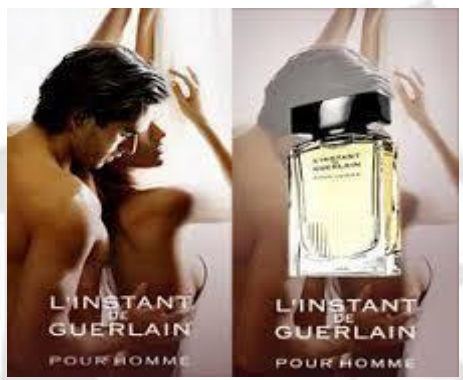

L'Instant pour homme GUERLAIN

Tendencia Espíritu de Seducción, boca y miradas provocativas, blanco y negro, look sexy. Ej. I am King Sean John, Guerlain Homme. Puede ser auténtico con un celebrity aunque deb

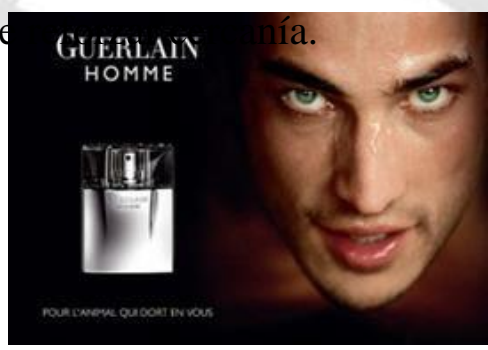

Guerlain Homme GUERLAIN

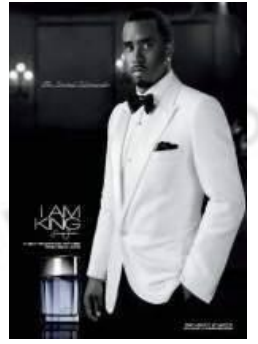

I am King SEAN JOHN 
Tendencia Technology: Inspirada en lenguaje futurista, joven, envases ultramodernos, colores plateados y metalizados. Ej. Pi Neo de Givenchy, Azzaro Twin. La ejecución de esta tendencia podría sentirse muy distante para nuestro target Ésika por transmitir excesiva modernidad, frialdad y baja seducción.

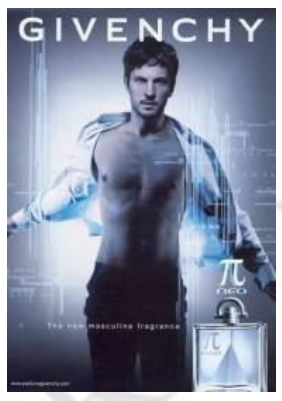

$\mathrm{Pi} \mathrm{NeO}$ GIVENCHY

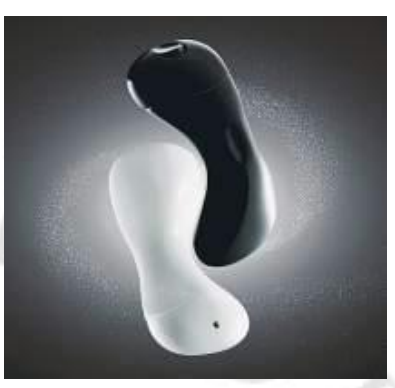

Azzaro Twin AZZARO

Tendencia Urban Vibe: Actitud urbana, que impulsa, presenta un lado energético cosmopolita. Ej.: Ultrared de Paco Rabanne, Hugo Element, de Hugo Boss. Concepto con dificultad para transmitir Storytelling, el consumidor latino quizás se cuestionaría: ¿qué

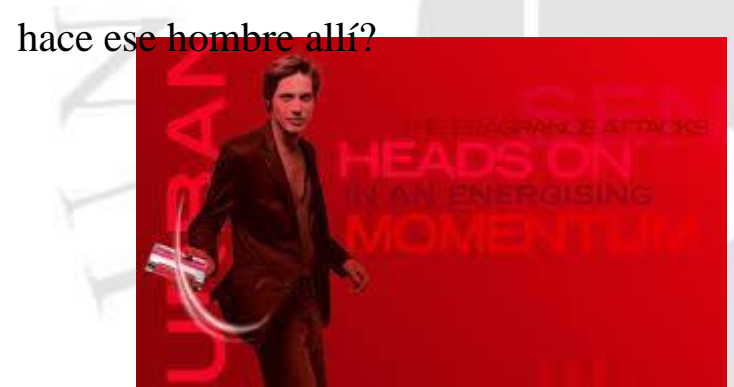

Ultrared Paco Rabanne

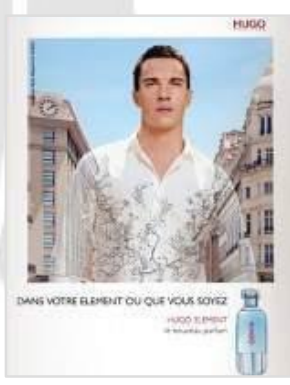

Hugo Element Hugo Boss

Tendencia Bling: Opulencia, quiere ser notado, exceso de dorados. Ej. One Million de Paco Rabanne, Diamonds for Men de Armani. Tendencia que transmite éxito a nuestro target, sin embargo el

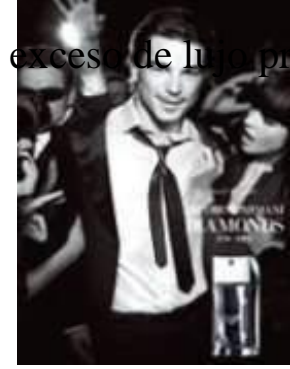
edomina sobre la seduccion?

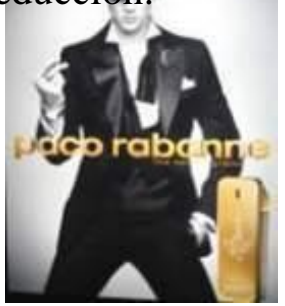


Tendencia True Luxe: Íconos de status masculino, calidad y reconocimiento, verdadero lujo, marca de distinción, negro y azul. Ej. Essence of Porsche, Jaguar, Baldessarini del Mar de Boss. Podría ser demasiado lejano, inalcanzable.

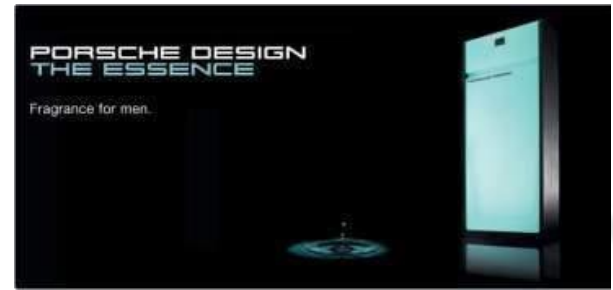

The Essence of Porsche PORSCHE

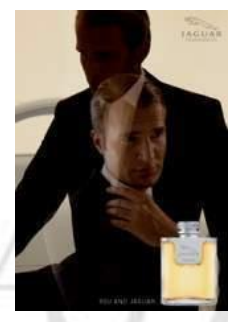

Jaguar JAGUAR

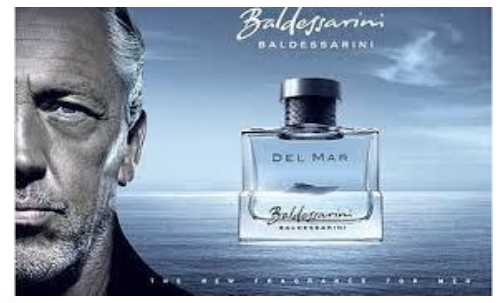

Baldessarini del Mar Boss

Tendencia Status Quo: presenta al hombre en una experiencia VIP, con presencia imponente, muy masculina, con fuerte personalidad, actitud y vestimenta sofisticada, a la vez que seductora y segura. Esta tendencia utiliza muchas imágenes en blanco y negro con acentos de color. Ejemplos: The One de Dolce \& Gabanna, Silver Shadow de Davidoff. El análisis de la tendencia concluyó que ésta era coherente con la imagen de un celebrity al transmitir seducción y sofisticación. El estudio verificaría la hipótesis de que los hombres querrían ser como este personaje mientras que las mujeres desearían estar con él. La sofisticación aportaría valor y por lo tanto percepción de duración en la fragancia reforzada con la presencia del celebrity ypensprecio de nivel A.
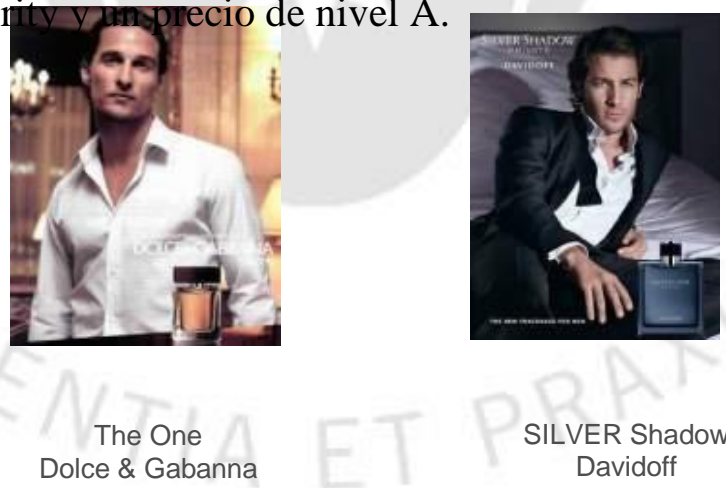

SILVER Shadow Davidoff

La tendencia seleccionada para la ruta conceptual del proyecto Hombre Irresistible fue

\section{Status Quo.}




\section{ANEXO 3: Casa Perfumista Symrise}

Symrise es una de las casas de perfumería más importantes del mundo junto con IFF, Firmenich y Givaudan. Las 4 casas han sido proveedores del Core List de Belcorp por muchos años siendo Symrise la casa con mayores éxitos en Belcorp. Es de origen alemán, con ventas anuales por encima de los 1.6 Billones de Euros. Sus orígenes datan de 1874 y cuenta con centros creativos en todo el mundo con 70 perfumistas y 7 Master Perfumers.

$$
\text { symrise }
$$

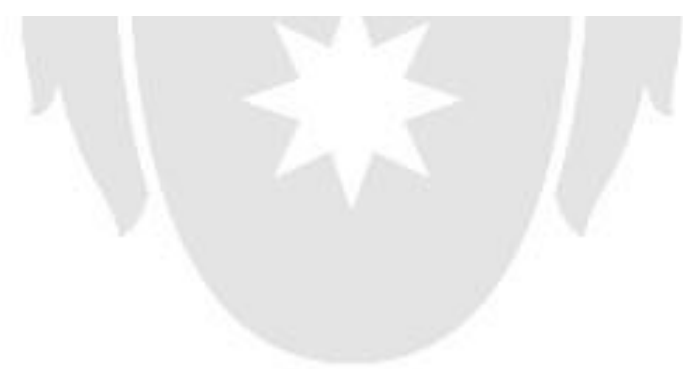




\section{ANEXO 4: La Competencia}

La competencia de las fragancias masculinas Ésika viene de venta directa y del canal retail. Para seleccionar al competidor directo se analizó el nivel de precio, capacidad, concepto, familia olfativa, ranking de mercado. El precio del proyecto Hombre Irresistible (Pulso) es de S/150 pudiendo llegar con descuento hasta S/74.50 para su presentación $100 \mathrm{ml}$.

\section{Venta Directa:}

UNIQUE/YANBAL: La marca Unique es la principal competencia. Con un nivel de precio $15 \%$ por encima de Pulso. Sus conceptos son sensuales y están bien ranqueadas generalmente en top 10. Tienen alto valor percibido y de duración, empaques modernos y elegantes. Sus aromas son creados por un equipo de perfumistas franceses desde una casa perfumista de Miami que trabaja muchos años con ellos.

Luego del análisis, Dendur queda descartada al tener un concepto más bien aventurero y no elegante. También descartadas fueron Osadía y Arom. Osadía por tener un aroma muy maderoso y especiado que no entra en nuestra selección de ruta aromática y Arom por tener un concepto de "caballero" el cual no transmite seducción. La fragancia seleccionada como competencia y benchmark fue Temptation. Esta selección fue retadora para el proyecto y se esperaba conquistar usuarios de las otras fragancias evaluadas también.

\begin{tabular}{|l|c|c|c|l|l|}
\hline & $\begin{array}{c}\text { Precio } \\
\text { Posiciona } \\
\text { miento S/ }\end{array}$ & $\begin{array}{c}\text { Precio Oferta } \\
\mathbf{5 0} \% \text { dscto }\end{array}$ & Capacidad & \multicolumn{1}{|c|}{ Slogan } & Descripción de aroma \\
\hline PULSO & 150 & 75 & $100 \mathrm{ml}$ & & \\
\hline Dendur & 172 & 109 & $75 \mathrm{ml}$ & Disfruta la aventura & Oriental con jengibre, tabaco y pimienta negra \\
\hline Temptation & 177 & 110 & $100 \mathrm{ml}$ & $\begin{array}{l}\text { Está en tu piel.Cambió a } \\
\text { Vuélvete irresistible }\end{array}$ & Fougere aromatic con menta, flor de naranjo y sándalo \\
\hline Osadía & 172 & 109 & $75 \mathrm{ml}$ & Provocación Latina & Maderoso con notas de étano, hierbabuena y limón \\
\hline Arom & 172 & 85 & $90 \mathrm{ml}$ & La huella de un caballero & Maderoso con notas de sándalo, romero y bergamota \\
\hline
\end{tabular}

Temptation

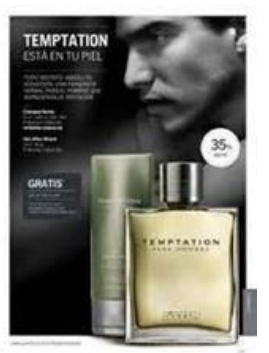

Dendur

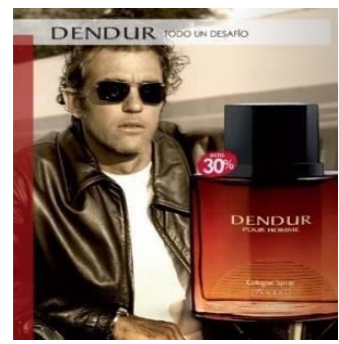

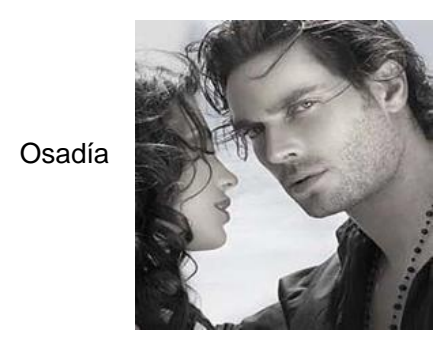


AVON: Las fragancias de Avon tienen precios más bajos y una percepción de valor menor a la de Ésika por lo que se consideró competencia secundaria. Además no tienen colocadas fragancias en top 10 del ranking de Colombia ni de Perú.

RETAIL: Este canal de distribución se ha vuelto muy accesible a más niveles socioeconómicos dada la facilidad de obtención de tarjetas de crédito de tiendas de departamento. En este caso analizamos a las fragancias Antonio Banderas. Estas fragancias no están ubicadas en los módulos de las marcas de mayor precio. Sin embargo, el glamour de aquellas marcas y la aspiracionalidad de los locales se irradian hacia éstas apoyando su percepción de valor.

Las fragancias Antonio Banderas pertenecen a la casa Puig de España. En 1997 lanzó su primera fragancia masculina con Diávolo (floral maderosa) que aún se comercializa con éxito. Desde ese entonces ha lanzado 57 perfumes masculinos y femeninos según la base de datos de Fragantica siendo la submarca King la última en aparecer en 2016. El posicionamiento del portafolio de Banderas es de Seductive Fragrances (Fragancias Seductoras). Su precio máximo para las fragancias masculinas es S/100.00 en las versiones de $100 \mathrm{ml}$. El precio de Diávolo es de sólo S/35.00 y tiene menor capacidad con $50 \mathrm{ml}$. A pesar del bajo precio, la fragancia puede transmitir valor al ser endosada por un celebrity altamente conocido como es Antonio Banderas. Aun cuando el ciclo de vida de esta fragancia es mucho mayor que cualquier otra fragancia con celebrity en el mundo, se descartó como competencia ya que en Colombia y Perú está ubicado por debajo del puesto 50 en el ranking. 


\section{ANEXO 5: Biografía perfumista.}

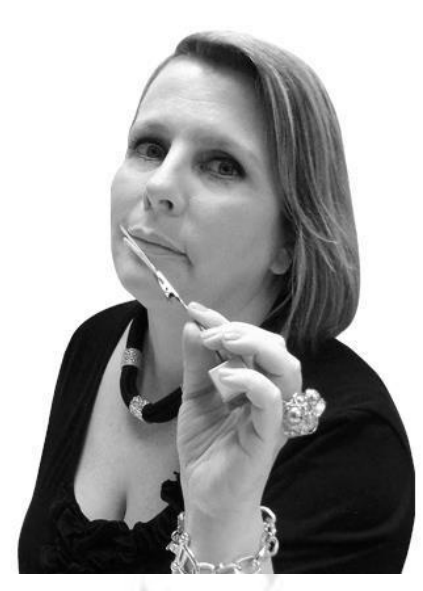

Fabienne Coupaye es una perfumista francesa senior radicada en México con amplia experiencia en el mercado latinoamericano. Es una apasionada por nuestras culturas y ha creado grandes éxitos para Belcorp.

Nacida en el sur de Francia, desde niña disfrutaba mezclando líquidos, cremas, plantas y lo que se encontrara pues sentía que todo olía mejor cuando se mezclaba con algo. Así inició su camino como perfumista... Ella es muy apasionada por su trabajo pues siente que sus creaciones hacen que la vida de las personas sea más bella. Sus creaciones son brillantes, alegres y sensitivas reflejando su personalidad. 


\section{ANEXO 6: Distribución de mercado por tipos de fragancia versus distribución interna Esika}

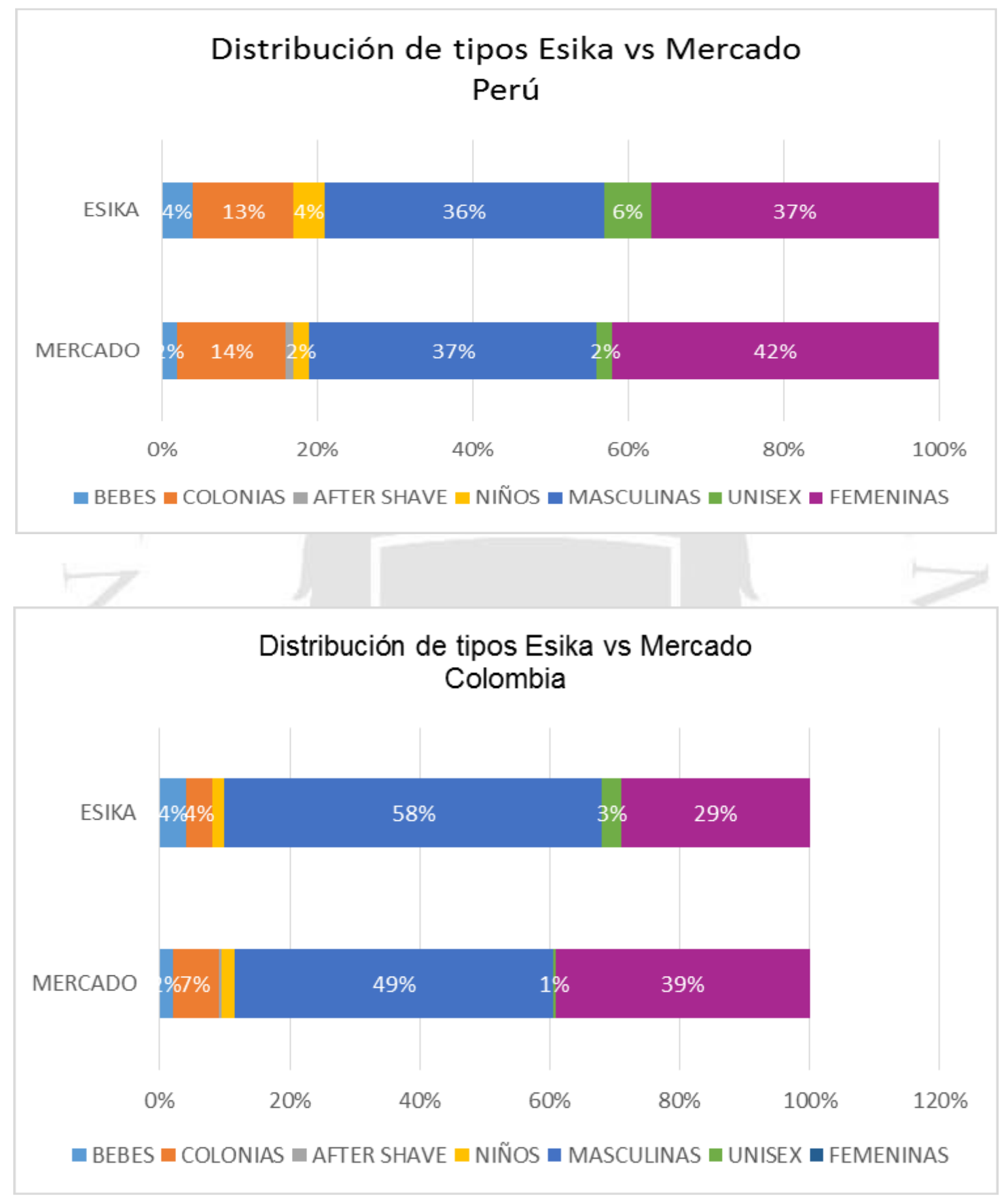

